\title{
Exchange Rate Economics: Where Do We Stand?
}

THE BROOKINGS PANEL on Economic Activity for the past ten years has mirrored much of the exciting theory and empirical work in open-economy macroeconomics. In the spirit of Brookings, the papers have explored what issues openness raises for macroeconomic management. The range of interests has been quite broad, beginning with William Branson's "new view of international capital movements" and including Marina Whitman's dismissal of "global monetarism" and many of the topics of the day from trade equations and oil to commodity booms, debt, and portfolio selection. ${ }^{1}$ The questions have been similar-how much independence there is for macroeconomic policy in an interdependent world; how important monetary factors are; or how can the interest rate be kept lower than the market will bear. The papers have emphasized the evolution of open-economy macroeconomics from the structure of the 1960 s-the Mundell-Fleming model-to a framework better suited to the analysis of inflation, expectations, and portfolio substitution.

This paper maintains the tradition of asking how international interdependence has impinged on macroeconomic variables and policy options. The paper takes as its frame of reference the experience with floating ex-

I am grateful for comments from members of the Brookings panel and from Stanley Fischer. Robert E. Cumby made many suggestions and provided generous research assistance. Financial support was provided by a grant from the National Science Foundation.

1. See William H. Branson, "Monetary Policy and the New View of International Capital Movements," BPEA, 2:1970, pp. 235-62; and Marina v. N. Whitman, "Global Monetarism and the Monetary Approach to the Balance of Payments," $B P E A, 3: 1975$, pp. 491-536. 
change rates and seeks to explain, in the light of today's theories, the pattern of exchange rate movements and policy responses.

The main lessons that emerge from the analysis concern the inadequacy of the monetary approach as a complete theory of exchange rate determination, the central role of the current account in influencing exchange rates, the suggestion that there is a deutsche mark shortage and, finally, the conclusion that an interest rate policy not oriented toward the external balance has aggravated exchange rate instability.

The paper is divided into two parts. In the first part, developments in exchange rates are analyzed using a variety of models, starting with the monetary approach, and leading from there to models of exchange rate dynamics and the current account. I show that unanticipated disturbances to the current account have been an important source of unanticipated movements in exchange rates. In addition, the structure of real returns on securities denominated in different currencies suggests that the deutsche mark should be occupying an important share in internationally diversified portfolios, and that substitution in that direction may well explain the persisting tendency for that currency to appreciate in real terms.

In the last part of the paper I address the important question of how the system of flexible exchange rates has been operated. A review of intervention and interest rate policies in key countries suggests that external constraints have not been predominant. On the contrary, interest rate policies have been pursued quite independently of a desire to finance imbalances in current accounts through capital flows; and that independence has led to growing requirements for intervention. The proposal by James Tobin for a tax on foreign exchange transactions is considered in this context.

The paper concludes with the demonstration that much of the observed instability in exchange rates has been due to unanticipated disturbances, with the forecasting errors broadly shared by governments and the public alike. The instability has been aggravated, however, by a failure to use monetary policy with a view to the external balance and by a failure to recognize portfolio shifts toward marks as part of the adjustment process to the regime of flexible exchange rates.

\section{Exchange Rate Theories and Empirical Evidence}

There are basically three views of the exchange rate. The first takes the exchange rate as the relative price of monies; the second, as the relative 
price of goods; and the third, the relative price of bonds. I regard any one of these views as a partial picture of exchange rate determination, although each may be especially important in explaining a particular historical episode. Still, it is useful to approach exchange rate theory not from the complex perspective of an all-encompassing model, but rather from the vantage point of a sharply articulated, partial model. The monetary approach is a good place to start. Although in the opinions of some of its proponents it represents a quite complete theory of the exchange rate, I will expand it to a more general theory by relaxing some of the special assumptions that are required if it is to stand on its own.

\section{THE MONETARY APPROACH}

At the outset of flexible rates in the 1970s, the literature emphasized a monetary interpretation of exchange rate determination. ${ }^{2}$ Most versions of the monetary approach assume strict purchasing power parity (PPP). Exchange rates move promptly in order to maintain the international linkage of prices. Thus there is no room for changes in the terms of trade. With $e$ denoting the logarithm of the home currency price of foreign exchange, and $p$ and $p^{*}$ denoting the logarithm of home and foreign prices, respectively, PPP implies ${ }^{3}$

$$
e=p-p^{*}
$$

where here and throughout the paper variables in lowercase (except interest rates) represent logarithms.

The next step in the monetary approach is to take prices as determined by domestic nominal money supply and real money demand. With real money demand depending on real income and the nominal interest rate, the expression becomes

$$
\begin{aligned}
p & =m-k y+h i \\
p^{*} & =m^{*}-k y^{*}+h i^{*},
\end{aligned}
$$

2. See the collection of papers in Scandinavian Journal of Economics, vol. 78, no. 2 (1976), pp. 133-412; the papers collected in Jacob A. Frenkel and Harry G. Johnson, eds., The Economics of Exchange Rates: Selected Studies (Addison-Wesley, 1978); John F. O. Bilson, "The Monetary Approach to the Exchange Rate: Some Empirical Evidence," IMF Staff Papers, vol. 25 (March 1978), pp. 48-75; and Jacob A. Frenkel, "Exchange Rates, Prices, and Money: Lessons from the 1920's," American Economic Review, vol. 70 (May 1980, Papers and Proceedings, 1979), pp. $235-42$.

3. Throughout the paper an asterisk denotes a foreign variable. 
where

$m=$ logarithm of nominal money

$k=$ income elasticity of real money demand

$y=$ logarithm of real income

$h=$ semilogarithmic interest response of real balances

$i=$ nominal interest rate.

Combining equations 1 and 2 yields the exchange rate equation of the monetary approach:

$$
e=m-m^{*}+h\left(i-i^{*}\right)-k\left(y-y^{*}\right),
$$

where coefficients are assumed to be equal for all countries.

The model establishes that relative changes in money supply, interest rate, and real income affect the exchange rate. An increase in the money supply at home leads to an equiproportionate depreciation. Because an increase in domestic real income raises the demand for real balances and thus leads to a fall in domestic prices, it induces an offsetting exchange appreciation. Relatively higher domestic interest rates, by contrast, reduce the demand for real balances, raise prices, and therefore bring about an exchange depreciation.

There are two ways to test the monetary approach. One recognizes that instantaneous PPP is an essential part of the monetary approach and directly tests whether PPP prevails. The second examines the explanatory power of econometric equations specified like equation 3 .

There is ample evidence accumulating that this assumption is not warranted. Not only does the short-term exchange rate deviate from a PPP path, but there are also cumulative deviations from that path that show substantial persistence. This is clearly brought out by table 1 , which shows annual inflation rates for consumer prices in the United States, five other major industrial countries, and a trade-weighted index of those countries. The table also shows the average annual appreciation of the foreign currencies relative to the dollar, bilaterally and as a group. Contrary to PPP theory, real exchange rates have not remained constant. The striking fact is that during the period from 1973 to 1979 , the annual rate of inflation in the United States averaged about 1 percentage point less than in the group of foreign countries, yet the dollar has depreciated at an average rate of over 1 percent a year. ${ }^{4}$ There has thus been an average annual

4. The comparison here is based on consumer prices; it holds, in general, for other price indexes also. 
Table 1. Inflation and Currency Appreciation in Major Industrial Countries, 1973-79

Annual average, in percent

\begin{tabular}{lcc}
\hline & \multicolumn{2}{c}{ Measure } \\
\cline { 2 - 3 } Country & $\begin{array}{c}\text { Consumer price } \\
\text { inflation }\end{array}$ & $\begin{array}{c}\text { Appreciation on } \\
\text { the dollar }\end{array}$ \\
\hline United States & 8.5 & $\ldots$ \\
Other major industrial countries & 9.4 & 1.4 \\
Canada & 9.2 & -2.6 \\
France & 10.7 & 0.7 \\
Germany & 4.6 & 6.4 \\
Japan & 9.9 & 3.6 \\
United Kingdom & 15.6 & -2.4 \\
\hline
\end{tabular}

Source: International Monetary Fund, International Financial Statistcs, vol. 33 (March 1980), series ahx for exchange rates and series 64 for prices.

a. These series are weighted averages of the respective individual series for the five foreign countries. The relative weights are derived from the International Monetary Fund's multilateral trade model. They are: Canada -0.2405 , France -0.1640 , Germany -0.2340 , Japan -0.2160 , and the United Kingdom0.1440 .

change in relative price levels adjusted for exchange rate movements (or a real depreciation of the dollar) of more than 2 percentage points. This substantial rate of real depreciation should attract attention and study rather than being confined to the error term. The evidence of table 1 is also reflected in figure 1 , which shows that the International Monetary Fund's multilateral nominal and real effective exchange rates of the dollar have moved together. Figure 2 illustrates how the nominal effective exchange rate has departed from, rather than simply offset, inflation differentials. ${ }^{5}$

The alternative approach to testing the monetary theory relies on evidence from regression equations. The empirical evidence reported in table 2 tests the explanatory power of the theory as specified by equation 3, using the dollar-mark exchange rate. The explanatory variables are relative nominal money supplies, relative real income levels, and nominal long-term and short-term interest differentials.

The long-term interest differential appears in the exchange rate equation either because, in addition to short-term interest rates, long-term rates measure one of the alternative costs of holding money or because they are taken as a proxy for anticipated inflation differentials. In either

5. Throughout the remainder of this paper the nominal effective exchange rate is this trade-weighted index of the five foreign countries of table 1, rather than the International Monetary Fund's published multilateral trade-weighted index. 


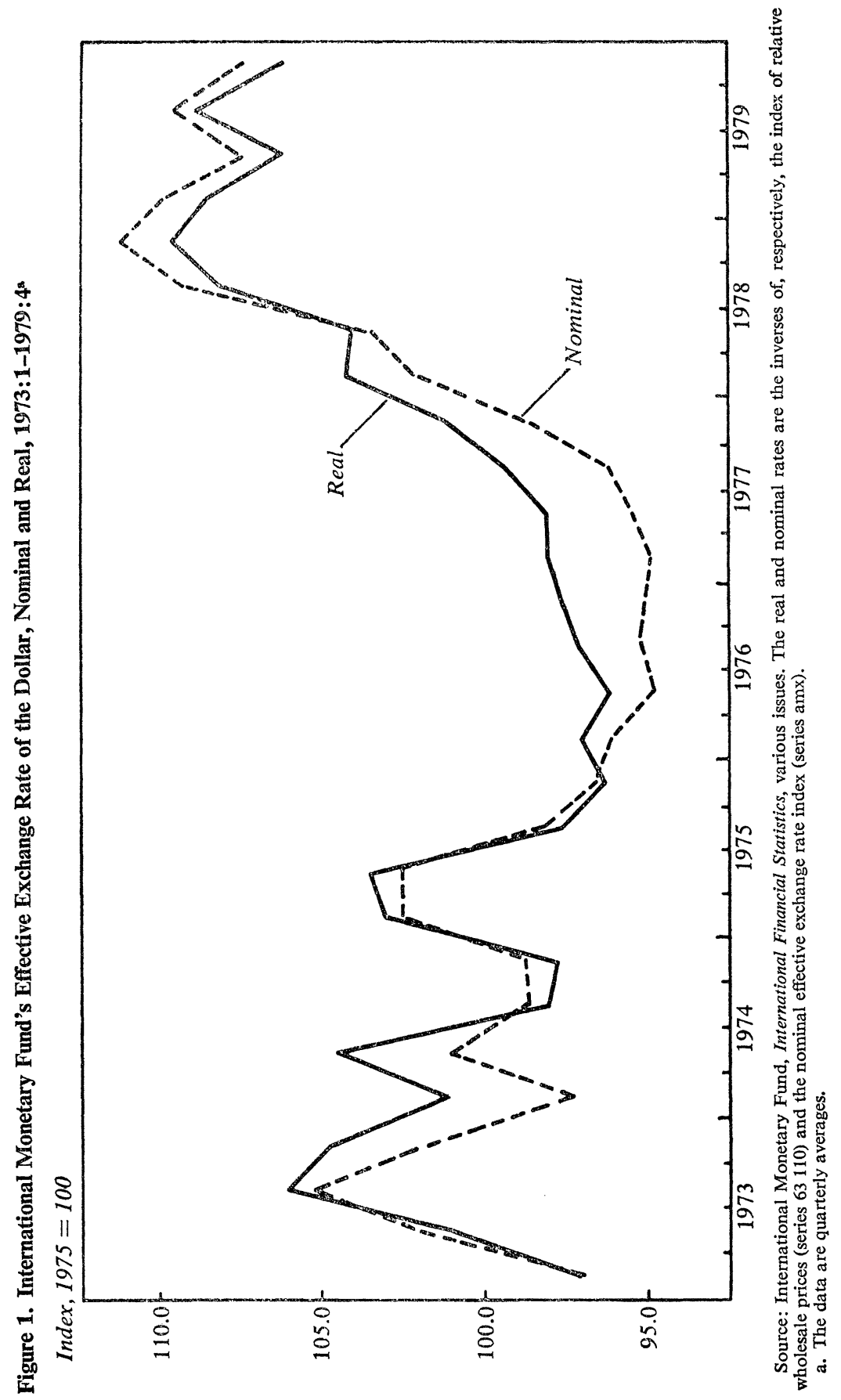




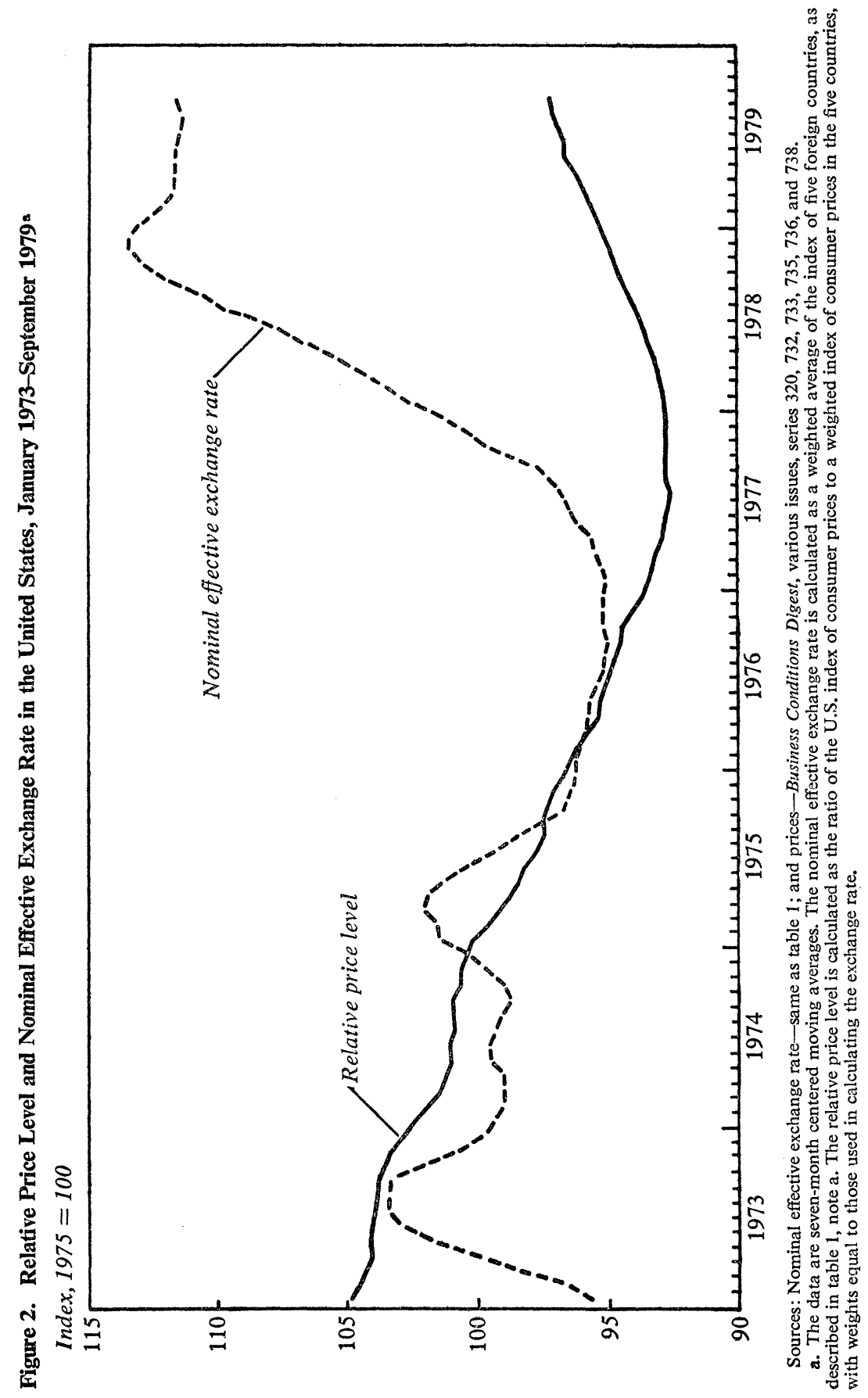




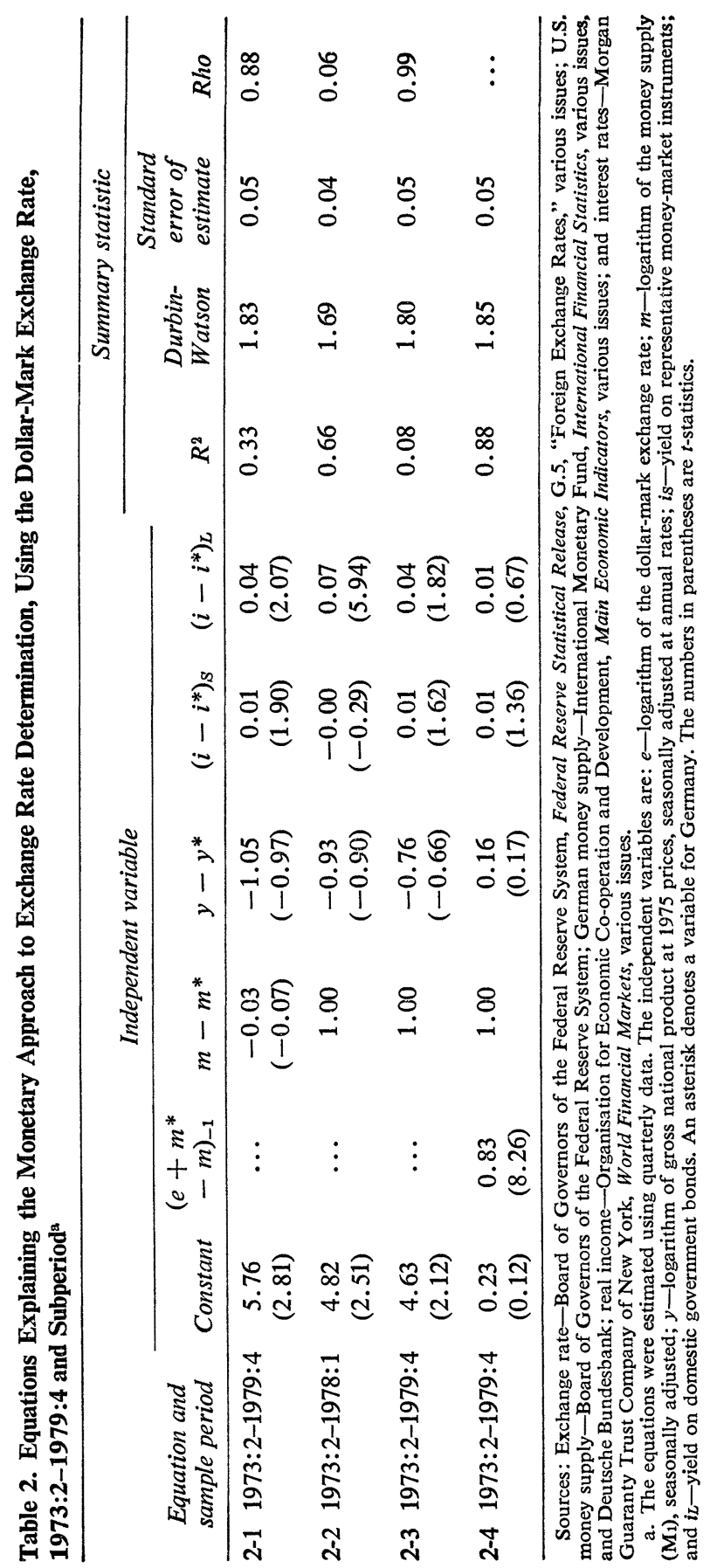


view, a rise in the domestic long-term interest rate differential leads to a reduction in real money demand and thus to higher prices and depreciation. ${ }^{6}$

The theory suggests that a rise in domestic relative income induces appreciation and that an increase in domestic interest rates induces depreciation. Equation 2-1 in table 2 tests this theory with quarterly data, with coefficients constrained to be equal for all countries. It offers little support for the monetary approach. Only a small fraction of the variance in the exchange rate is explained, and there is a high (0.88) estimated coefficient of serial correlation. Although interest rates have the expected sign and are significantly different from zero, the coefficient of relative monies is actually negative, but it is insignificant.

The coefficient of relative monies in the remaining equations is constrained to unity. Equations 2-2 and 2-3 differ in sample period and demonstrate the instability of equation 3 . For the complete sample period the equation has negligible explanatory power. Equation 2-4 allows for lagged adjustment in real balances by introducing the lagged dependent variable as an explanatory variable. ${ }^{7}$ Only the lagged adjustment term appears significant in this formulation.

The evidence on PPP and the econometric evidence reported here leave little doubt that the monetary approach in the form of equation 3 is an unsatisfactory theory of exchange rate determination. The key link between the exchange rate and PPP fails to hold, and any reasonable model must include a theory of real exchange rate determination.

The monetary approach was an important stepping stone of empirical research in international monetary economics and a plausible, if bold, hypothesis. Together with the asset market approach, it reflected a reaction to elasticity models of the exchange rate and, in that respect, was a substantial contribution. Both approaches share the partial equilibrium

6. For further discussion of the roles of long-term and short-term interest differentials, see Jeffrey A. Frankel, "On the Mark: A Theory of Floating Exchange Rates Based on Real Interest Differentials," American Economic Review, vol. 69 (September 1979), pp. 610-22.

7. For further discussion see Rudiger Dornbusch, "Monetary Policy under Exchange-Rate Flexibility," in Federal Reserve Bank of Boston, Managed Exchange Rate Flexibility: The Recent Experience, Conference Series, 20 (FRBB, 1979), pp. 90-122; Frankel, "On the Mark"; and P. Hooper and J. Morton, "Fluctuations in the Dollar: A Model of Nominal and Real Exchange Rate Determination" (Board of Governors of the Federal Reserve System, October 1979). 
view that exchange rates are determined by the conditions of stock equilibrium in the asset markets. They ignore other factors important to a general equilibrium analysis. I turn next to a broader model that reintroduces the more traditional aspects of exchange rate determination-the current account, wealth effects, expectations, and relative prices.

\section{A GENERAL MODEL OF EXCHANGE RATES}

If strict PPP is abandoned, the way is clear for a broad approach to modeling exchange rate determination. A first step here is the traditional Mundell-Fleming model that remains, with some adaptations, the backbone of macroeconomic models of the exchange rate. ${ }^{8}$ This model assumes that domestic prices are fixed in each home currency so that the exchange rate sets the terms of trade or the price of domestic goods relative to imports. Capital is fully mobile internationally and, with perfect substitutability between home and foreign securities (ignoring exchange rate expectations), interest rates are equalized internationally. Output is demand-determined.

Suppose, in this setting, that monetary expansion occurs at home. The resulting decline in interest rates leads to an international differential that brings about an incipient capital outflow. The exchange rate depreciates and, with elasticity conditions satisfied, demand shifts toward domestic goods. The induced increase in output leads to a rise in income and money demand until equality among international interest rates is restored at a higher level of output with a lower real exchange rate.

An expansion in demand for home output arising from fiscal policy or an exogenous shift in demand leads to an increase in income and money demand, and hence a tendency for interest rates to increase. The induced capital inflows bring about exchange rate appreciation, a loss in competitiveness, and hence a deterioration in the current balance that dampens or offsets the expansion. This result is clearly a curiosity, and I return to it below.

An extended Mundell-Fleming model can be derived by relaxing five key restrictive assumptions: fixed prices, the fully demand-determined level of output, the absence of exchange rate expectations, the absence of a role for the current account in exchange rate determination, and the

8. For an exposition and further references, see Rudiger Dornbusch, Open Economy Macroeconomics (Basic Books, forthcoming in 1980). 
perfect substitutability of domestic and foreign securities. The first three assumptions are readily relaxed. ${ }^{9}$

Rational expectations and long-run neoclassical features such as full employment are included in the extended Mundell-Fleming model. The increase in demand again brings an immediate nominal and real appreciation that restores demand to the full employment level through an offsetting deterioration in the current account, and monetary expansion leads to an immediate depreciation of the nominal and real exchange rate. Moreover, the exchange rate must overshoot, depreciating proportionately more than the expansion in money, if asset markets adjust more rapidly than goods markets. The domestic interest rate falls relative to those abroad, and asset markets will be in balance only if the exchange rate initially overshoots, so that there are corresponding expectations of currency appreciation. ${ }^{10}$

The extended Mundell-Fleming model is a first approach to expanding exchange rate theory in the absence of PPP that allows for short-run real effects of monetary disturbances and that permits the possibility of permanent changes in relative prices in response to changes in the pattern of world demand. By introducing rational expectations, the model focuses on "news" as the determinant of unanticipated changes in the exchange rate. Over time the exchange rate follows a path delineated by interest differentials. News about monetary developments or the state of demand bring about immediate changes in the level and path of the exchange rate. These ideas can be incorporated by distinguishing between actual and antici-

9. See Rudiger Dornbusch, "Expectations and Exchange Rate Dynamics," Journal of Political Economy, vol. 84 (December 1976), pp. 1161-76, and Open Economy Macroeconomics.

10. The model is made up of the condition of monetary equilibrium,

$$
m-p=k y-h i
$$

the condition of equalization of interest rates, adjusted for anticipated depreciation, $\dot{e}$,

$$
i=i^{*}+\dot{e}
$$

and the condition of equilibrium in the goods market,

$$
y=a(e-p)+u,
$$

where it is assumed, for expository simplicity, that there is no direct effect of interest rates on aggregate demand. The rate of inflation (relative to trend) is determined by the output gap, $y-\bar{y}$; that is, $\dot{p}=b(y-\bar{y})$. The model determines at a point in time the level of output and the exchange rate, as well as the rate of inflation and depreciation, as a function of prices. Shifts in demand, shown by shifts in $u$, lead to immediate offsetting changes in the real exchange rate. 
pated depreciation, $\dot{e}^{\prime}$ and $\dot{e}$, respectively. With perfect asset substitutability, the actual rate of depreciation is the sum of anticipated depreciation, which equals the nominal interest differential, $i-i^{*}$, and the effect of news, which is given by the difference between actual and anticipated depreciation,

$$
\dot{e}^{\prime}=\left(i-i^{*}\right)+\left(\dot{e}^{\prime}-\dot{e}\right) .
$$

The relevant news in this model is changes in monetary conditions and in the demand for domestic output.

The model retains the uncomfortable property that any increase in demand for home output, whether through fiscal expansion or increased net exports, leads to nominal and real appreciation because the only role of the current account is as a component of demand. Imbalances in the current account have no medium-term feedback on the economy, either in goods markets or in asset markets. The analysis can now be expanded to introduce the role of the current account.

Suppose that in the goods market demand for home output depends not only on income and the terms of trade but also on real wealth. A rise in real wealth would be expected to increase real spending and demand for domestic goods. A rise in wealth thus creates an excess demand, which, to maintain output at full employment, would have to be offset by the expenditure-shifting effect of a real exchange rate appreciation. In the diagram below the $y$ schedule is seen as the combination of real exchange rates-defined as the ratio of the price of imports to domestic goods imports - and the level of real wealth, $w$, which is consistent with output at full employment. ${ }^{11}$

The current account is balanced along the schedule $\dot{w}=0$. With more wealth there is increased spending and thus a tendency for an external deficit. To restore external balance, the real exchange rate must depreciate, thus shifting demand from foreign goods toward home output, and

11. In terms of note 10 , the equilibrium condition in the goods market now becomes $y=J(e-p, w, u)$, where $w$ denotes the level of real wealth and a rise in real wealth increases demand for home output. Real balances are excluded from the definition of real wealth. The current account is equal to the rate of change of real wealth, $\dot{w}$; that is, $\dot{w}=H(e-p, w, y, v)$, where $v$ is a shift parameter. The current account improves with real depreciation but deteriorates with an increase in income or wealth as both induce increased spending. For a more complete model along these lines see Rudiger Dornbusch and Stanley Fischer, "Exchange Rates and the Current Account," American Economic Review (forthcoming in December 1980). 


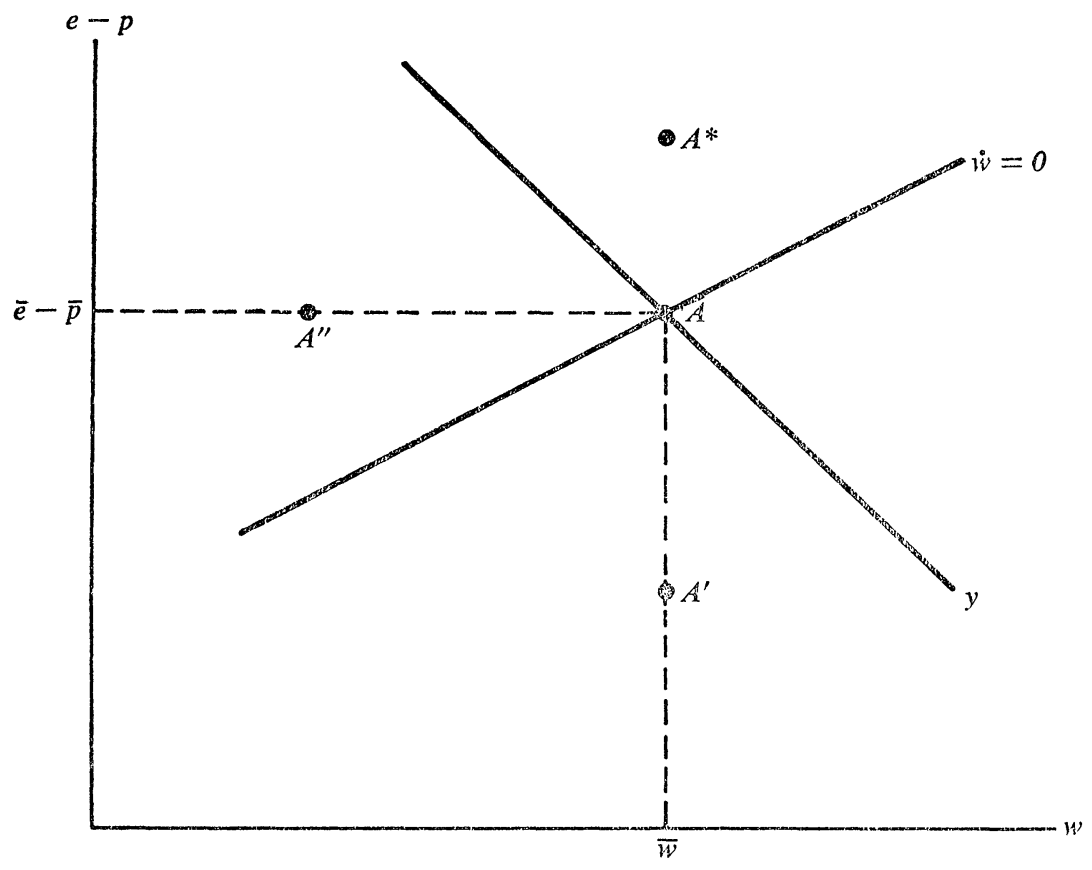

thereby restoring external balance. Accordingly, the external balance schedule is positively sloped; points above the schedule correspond to a surplus and points below to a deficit. Furthermore, a surplus implies net acquisition of claims on the rest of the world and hence growing real wealth; the converse is true for a deficit.

The extended framework is helpful in identifying the long-run equilibrium of the economy, its determinants, and some of the factors that affect the dynamics. The diagram shows that long-run equilibrium occurs for real variables-real wealth and the terms of trade or real exchange rate. At point $A$, demand for domestic output is at full employment and the current account is in equilibrium or, equivalently, income equals expenditure. In the background is the monetary sector that specifies the price level and the nominal exchange rate.

The expanded model makes possible the immediate interpretation of a demand shift or increase in net exports. With a permanent increase in net exports there is an excess demand for domestic goods and an equal surplus. To restore internal and external balance simultaneously, all that is required is nominal and real appreciation. A demand shift thus leads to an 
instantaneous real and nominal appreciation to a point like $A^{\prime}$, with no further adjustments needed. By contrast, a rise in spending on both home and traded goods in the pattern of average expenditures will leave the equilibrium composition of spending unchanged, and thus only leads to a change in long-run wealth at point $A^{\prime \prime}$. Over time the economy will reduce its stock of assets until spending has declined sufficiently for the initial real exchange rate to be reestablished. The adjustment process depends, of course, on the interaction between goods markets and the monetary sector.

The uncomfortable fact remains that even in this model there is a shortrun tendency for an expenditure increase to induce appreciation. The reason is, once again, that the increase in demand leads to a rise in income and thus to higher money demand and increased interest rates. Because the long-run real and nominal exchange rate are unchanged, higher interest rates are only compatible with equilibrium in the international capital market if there is the expectation of depreciating currency. That expectation will arise through an initial real and nominal appreciation. Thus in the diagram above the real exchange rate would appreciate in the short run to a point like $A^{\prime}$. Over time, as the stock of assets is reduced through the current account deficit and demand falls, the real exchange rate depreciates until point $A^{\prime \prime}$ is reached. An immediate appreciation is again implied when the dynamics are governed by short-run price stickiness and rational expectations in asset markets.

Expansionary fiscal policy will only lead to an initial depreciation of the nominal and real exchange rate if, in addition to the expectation of an unchanged long-run real exchange rate, the expectation of a nominal depreciation is introduced. There is good reason for such an assumption if one considers a fiscal expansion as one that is accommodated by an expansion in nominal money so that the nominal interest rate is unchanged. And it is the only way to generate this result in the model. With an accommodating nominal money expansion, the expectation of a higher longrun level of prices with unchanged terms of trade leads to an immediate depreciation of the real exchange rate to a point like $A^{*}$ in the diagram. At $A^{*}$, assuming smooth adjustment, there is a current account deficit (the $\dot{w}=0$ locus shifts leftward, as does the $y$ schedule) combined with an output expansion. From $A^{*}$ the economy moves toward $A^{\prime \prime}$; wealth declines, and the real exchange rate appreciates to restore the initial terms of trade. 
The final exercise to be considered is a sustained increase in the rate of money creation. The expectation of higher long-run inflation, and of the induced increase in velocity, implies a one-time rise in the cost of foreign currency. With rational expectations, the currency immediately depreciates before prices rise and the economy moves to a point like $A^{*}$ in the diagram. But because in the long run the real exchange rate and real wealth are unchanged, and because the real depreciation induces a current account surplus at $A^{*}$ (this time the schedules remain the same), a clockwise adjustment occurs until the economy returns to point $A$. Output is initially above full employment in the adjustment process as a consequence of the overdepreciation; assets are accumulated through the current account; and the real exchange rate appreciates. The current account surplus and the income expansion are, of course, only transitory, as is the real depreciation.

I have described a fairly eclectic general equilibrium model of goods markets and asset markets, expectations, and current account adjustment. The model is capable of accounting for some of the exchange rate experience in the United States, in particular the transitory deviations from PPP, permanent changes in the real exchange rate, and jumps of exchange rates in response to new information. This latter phenomenon is a key feature of the model and implies that, because of the differential speed of adjustment in goods markets and asset markets, even purely monetary disturbances have transitory real effects.

\section{TESTING THE NEWS}

In this section I offer some tests of the exchange rate model developed above. I showed there that unanticipated changes in aggregate demand or in net exports affect the equilibrium exchange rate. In particular, an accommodated increase in demand leads to depreciation and a current account deficit; an unanticipated increase in net exports leads to an appreciation. A monetary expansion induces depreciation, income growth, and a transitory current account surplus.

Perhaps the central implication of the rational expectations model is that it must be tested in "news form." With the assumption that asset markets are efficient, all available information is immediately embodied in asset prices and exchange rates. If one disregards for now the possibility of 
a risk premium, deviations of exchange rates from the path implied by interest differentials are thus entirely due to news. ${ }^{12}$

The extended model first distinguishes news of three kinds as important determinants of unanticipated changes in exchange rates: news about the current account, cyclical or demand factors, and interest rates. To test this model empirically, I use the definition of unanticipated depreciation as the difference between the actual depreciation and interest differentials, $\dot{e}^{\prime}-\left(i-i^{*}\right)$. The theory suggests that an unanticipated surplus in the current account leads to appreciation, while an unanticipated increase in demand that is accommodated will lead to depreciation. Denoting news about the current account, cyclical movements, and interest rates as $C A E, C Y C$, and $I N N$, respectively, the equation becomes

$$
\dot{e}^{\prime}-\left(i-i^{*}\right)=\alpha_{0}-\alpha_{1} C A E+\alpha_{2} C Y C-\alpha_{3} C Y C^{*}+\alpha_{4} I N N,
$$

where in the absence of a risk premium, $\alpha_{0}$ is expected to be zero.

As measures of the current account and cyclical news I use the official forecast errors of the Organisation for Economic Co-operation and Development, which publishes biannual six-month forecasts for current account balances and real growth of major industrial countries. ${ }^{13}$ Combined with the subsequently realized current account balances and growth rates, these forecasts yield time series data for the news shown in the explanatory variables. Because these forecasts are prepared through multilateral intergovernmental consultation, they are broadly representative of informed opinion about growth and current account balances.

Consider next the unanticipated depreciation, $\dot{e}^{\prime}-\left(i-i^{*}\right)$, for the nominal effective exchange rate of the dollar (defined in table 1 ). The

12. The idea of testing rational expectations models in news form is familiar from the work of Robert J. Barro in macroeconomics. In the context of exchange rate problems the idea is rapidly becoming accepted. See in particular Dornbusch, "Monetary Policy"; Peter Isard, "Expected and Unexpected Changes in Interest Rates," International Finance Discussion Paper 145 (Board of Governors of the Federal Reserve System, June 1979); Michael P. Dooley and Peter Isard, "The PortfolioBalance Model of Exchange Rates," International Finance Discussion Paper 141 (Board of Governors of the Federal Reserve System, May 1979); extensive work by Michael Mussa, in particular his "Empirical Regularities in the Behavior of Exchange Rates and Theories of the Foreign Exchange Market," in Karl Brunner and Allan H. Meltzer, Policies for Employment, Prices, and Exchange Rates, CarnegieRochester Conference Series on Public Policy, vol. 11 (Amsterdam: North-Holland, 1979), pp. 9-57, as well as references given there.

13. See Organisation for Economic Co-operation and Development, OECD Economic Outlook, various issues. 
monthly series is shown in figure 3 , together with the series for anticipated depreciation given by $i-i^{*}$ (both expressed as annual percentage rates). As the figure clearly illustrates, unanticipated changes constitute nearly all the actual variation in exchange rates.

Regression equations explaining unanticipated depreciation of the dollar against a trade-weighted mixture of other currencies are shown in table 3. Equation 3-1 explains the unanticipated depreciation of the dollar by the current account and cyclical errors. The cyclical errors for the United States and five foreign countries are constrained to be of equal and opposite sign in this equation. The equation accounts for much of the unanticipated depreciation, and evidence of serial correlation does not appear in the errors. The coefficients do have the expected signs. The coefficient on the current account news is significant. An unanticipated current account surplus in the United States of $\$ 1$ billion is worth half a percent of appreciation. The coefficient on the cyclical forecast error indicates that unanticipated growth leads to depreciation. But it is not significantly different from zero. Perhaps this reflects the fiscal expansion phenomenon discussed above.

Equations 3-2 and 3-3 include unanticipated changes in interest rates. Ideally the term structure of interest rates should be used to measure innovations; but here, because of the complexity of deriving such series, residuals from an autoregression of the short-term interest differential have been used. The equations show that unanticipated increases in shortterm interest differentials appear with a positive coefficient that is significant. The interest differential may reflect a causal role for unanticipated changes in the term structure, inflation news, or cyclical effects as suggested by a comparison of equations 3-1 and 3-2 in the table. ${ }^{14}$

Table 4 presents similar equations for the dollar-mark and dollar-yen exchange rates. Consider first the case of Japan. Equation 4-1 shows quite strikingly the role of current account errors and cyclical errors. An unanticipated surplus in the Japanese current account leads to dollar depreciation or yen appreciation. A cyclical expansion in Japan induces a yen depreciation. Both the coefficients of $C A E$ and $C Y C$ are significantly dif-

14. Frenkel reports regressions of the level of the exchange rate on lagged forward rates, interest differentials, and interest innovations, the last appearing with a positive coefficient. He attributes the positive coefficient to inflation news. See Jacob A. Frenkel, "Flexible Exchange Rates in the 1970's," Working Paper 450 (National Bureau of Economic Research, 1980), pp. 34-37. In my equations the introduction of inflation news yields a negative, insignificant coefficient. 


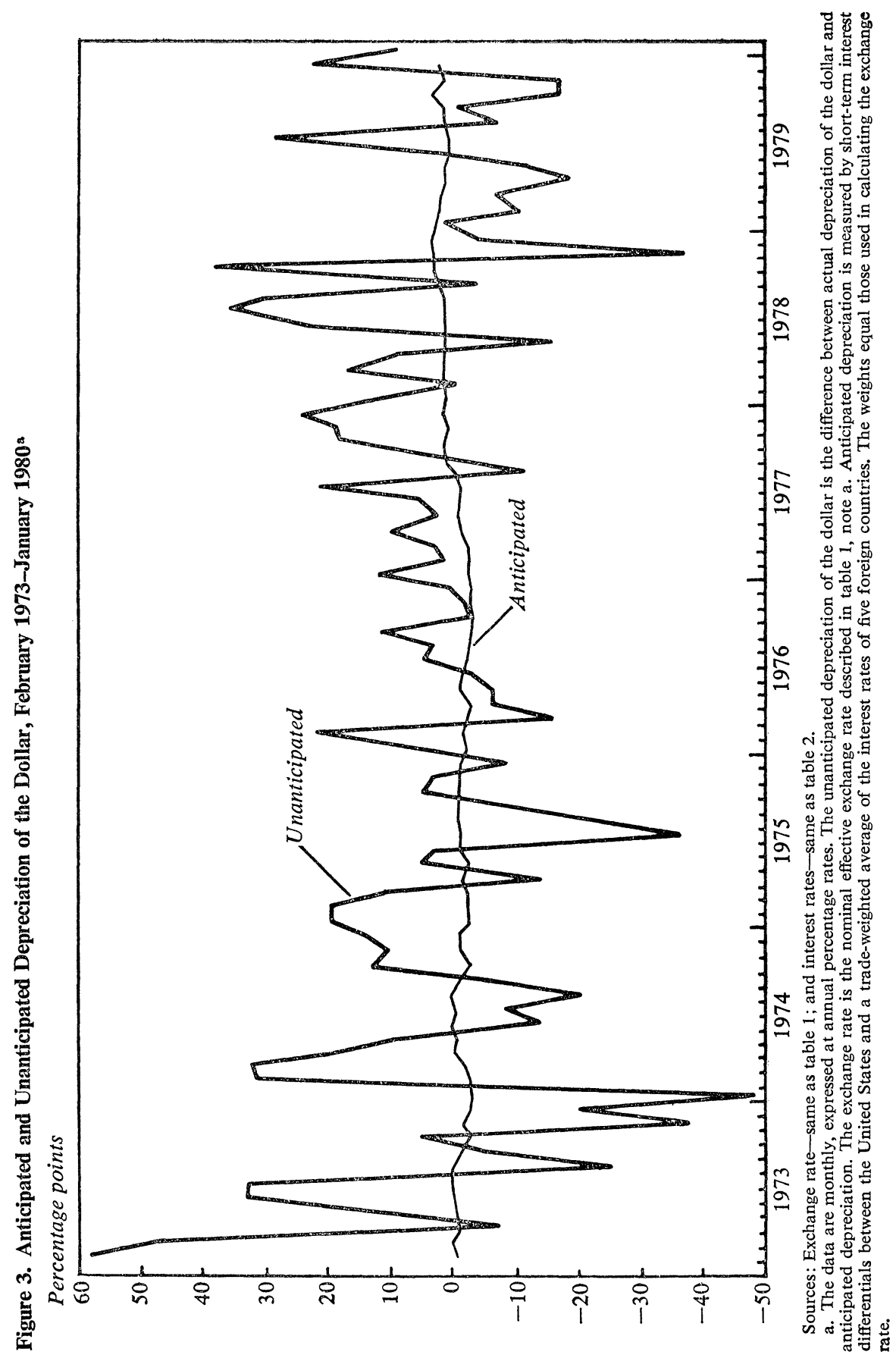




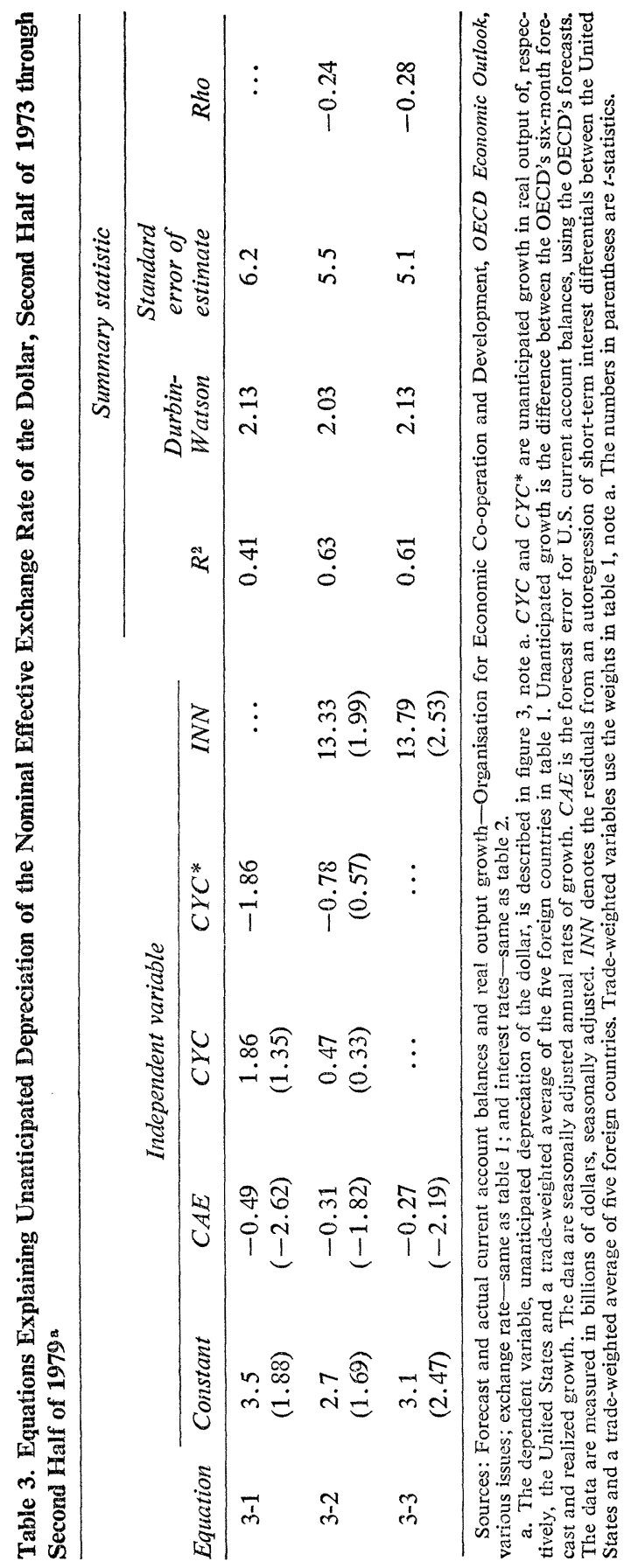




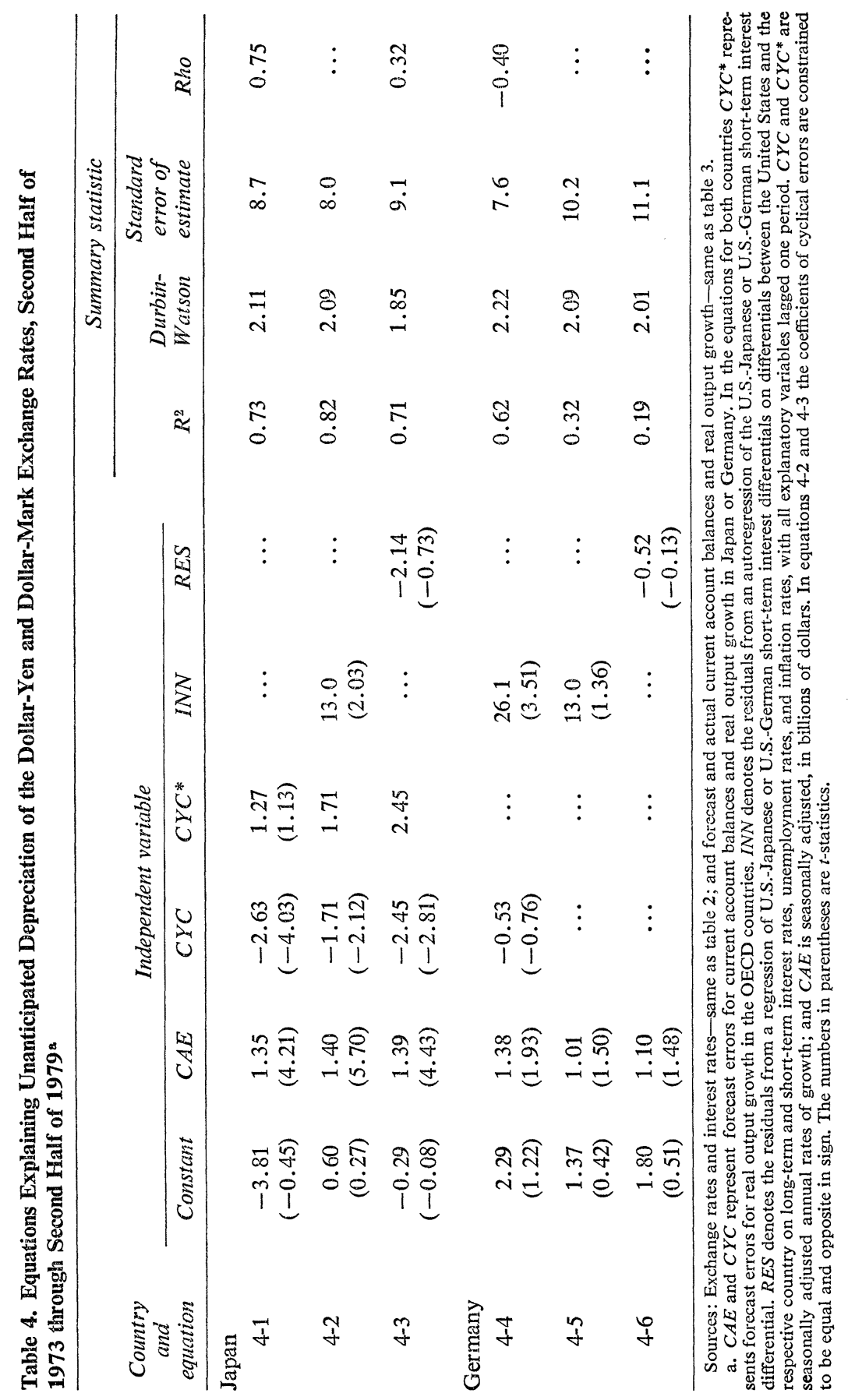


ferent from zero. The equation explains a large portion of the unanticipated depreciation. Unlike equation 3-3 for the United States in table 3, the constant terms are not significantly different from zero.

Equations 4-2 and 4-3 include interest rate news. The innovations in equation 4-2 are from an autoregression of the interest differential. In equation 4-3 the interest variable is residuals from an interest differential equation. The roles of the two interest rate innovations are quite different. The former have a significant positive coefficient reducing the magnitude and significance of the cyclical effects; the latter, which are more nearly orthogonal to cyclical effects, appear with a negative and insignificant coefficient. The same pattern is observed in the equations for Germany.

Unlike the dollar-yen exchange rate, unanticipated movements in the dollar-mark rate are not dominated by news about cyclical or current account events. Unanticipated improvements in the current account of Germany lead to a dollar depreciation, but the coefficient on the current account and cyclical innovations variables are not significantly different from zero. Innovations from an autoregression of interest differentials do play a part in explaining exchange rate movements in equation 4-4. But in 4-6 the residuals from a reaction function for the interest differential, which is discussed below, turn out to be insignificant. I argue there that portfolio shifts may well be the explanation for these results.

The empirical analysis confirms that unanticipated real and financial disturbances bring about unexpected movements in the exchange rate. To that extent, the preceding theory is confirmed. Whether the size of exchange rate movements stands in reasonable relation to the disturbance remains an open question. Clearly the answer depends not only on the structural parameters, including trade elasticities, but also on the expected persistence of the disturbance. The more persistent the disturbance, other things being equal, the larger the required change in the real exchange rate.

PORTFOLIO DIVERSIFICATION AND THE

\section{DEUTSCHE MARK SHORTAGE}

The analysis so far has largely excluded portfolio balance and its implications for exchange rates. The models considered share the assumption of perfect substitutability of home and foreign securities on a depreciationadjusted basis, thus leaving no room for shifts in wealth or relative asset supplies to affect the balance in asset markets. I now depart from this as- 
sumption to see what insights a broader treatment of portfolio choice will yield.

A starting point is the hypothesis that money demand depends not only on income, the conventional transactions variable, but also on wealth. Shifts in wealth induced by current account imbalances create monetary imbalances leading to adjustments in long-run price level expectations and thus to exchange rate movements. This effect does not presuppose imperfect asset substitutability, although it is entirely compatible with it. With perfect mobility of capital, this specification of money demand implies that the real money demand of a country with a surplus rises while it falls abroad. The relative price level of the country with a surplus declines and, therefore, exchange rates for given terms of trade tend to appreciate. ${ }^{15}$

The results, of course, follow from a strong assumption about distribution effects. Monies are treated as nontraded assets, the demand for which is affected by an international redistribution of wealth. In the absence of an empirically significant wealth effect on money demand, this theory probably does not go very far in explaining exchange rates.

An alternative and more persuasive role for portfolio effects arises in the context of imperfect asset substitutability. With uncertain real returns, portfolio diversification makes assets imperfect substitutes and gives rise to determinate demands for the respective securities and to real yield differentials or a risk premium. ${ }^{16}$

15. This variant of the current account theory of exchange rates is emphasized in Rudiger Dornbusch, "Capital Mobility, Flexible Exchange Rates and Macroeconomic Equilibrium," in E. Claassen and P. Salin, eds., Recent Issues in International Monetary Economics, Studies in Monetary Economies, vol. 2 (Amsterdam: NorthHolland, 1976), pp. 261-78; and Pentti J. K. Kouri, "The Exchange Rate and the Balance of Payments in the Short Run and in the Long Run: A Monetary Approach," Scandinavian Journal of Economics, vol. 78, no. 2 (1976), pp. 280-304.

16. This line of research has been particularly pursued in W. H. Branson, "Asset Markets and Relative Prices in Exchange Rate Determination," Sozialwissenschaftliche Annalen, vol. 1 (1977), pp. 69-89; and William H. Branson, Hannu Halttunen, and Paul Masson, "Exchange Rates in the Short Run: The Dollar-Deutschemark Rate," European Economic Review, vol. 10 (December 1977), pp. 303-24. See also Michael G. Porter, "Exchange Rates, Current Accounts and Economic Activity-A Survey of Some Theoretical and Empirical Issues" (Board of Governors of the Federal Reserve System, June 1979); Dooley and Isard, "Portfolio-Balance Model"; Maurice Obstfeld, "Capital Mobility and Monetary Policy under Fixed and Flexible Exchange Rates" (Ph.D. dissertation, Massachusetts Institute of Technology, 1979); Pentti J. K. Kouri and Jorge Braga de Macedo, "Exchange Rates and the Inter- 
The portfolio model provides an explanation of the unanticipated mark appreciation that is only poorly accounted for by the current account and cyclical innovations. I argue that the system of flexible exchange rates and the macroeconomic policies and disturbances have created an incentive for portfolio diversification, that the mark would occupy a large share in an efficiently diversified portfolio, and that the resulting portfolio shifts or capital flows account for some of the unanticipated appreciation.

Table 5 shows the realized means and variances of the real returns on assets denominated in different currencies. The real yield in each instance is the nominal short-term interest rate plus the depreciation of the dollar relative to the particular currency, thus creating dollar returns, less the rate of inflation of the dollar price index of manufactures in world trade. The real return data thus are comparable and appropriate for an investor that does not have a particular local habitat.

Concentrating on the 1976-79 period, note that both the mark and the dollar are relatively stable (low-variance) assets and that their returns are negatively correlated. The dollar has a negative mean return, while the mark has a positive one.

In principle, an efficiently diversified portfolio is a wide-ranging one, including bonds, amusement parks, old-age homes, and so on. In practice, investors develop a narrow portfolio, highly concentrated in home securities with a small range of international claims. Suppose, to make a point, that only dollars and marks are part of the portfolio of international assets. What would be their respective shares? The relevant model of utility-maximizing portfolio diversification shows that the share of mark assets, using the distribution of returns of table 5 , is 56 percent. This corresponds to a 50 percent share of bonds denominated in marks in the minimum-variance portfolio plus a 6 percent share in a speculative mark position. ${ }^{17}$ The speculative position in marks, motivated by the differen-

national Adjustment Process," BPEA, 1:1978, pp. 111-50; and Rudiger Dornbusch, "A Portfolio Balance Model of the Open Economy," Journal of Monetary Economics, vol. 1 (January 1975), pp. 3-20.

17. Let $w$ be the initial level of real wealth; $r$ and $r^{*}$, the random real returns on home and foreign securities; and $x$, the portfolio share of foreign securities. End-of-period wealth then is random and equal to $\tilde{w}=w(1+r)+x w\left(r^{*}-r\right)$. Utility is a function of the mean and variance of end-of-period wealth:

$$
U=U\left(\bar{w}, s_{\tilde{w}}^{2}\right) .
$$

The mean and variance of wealth are defined as 


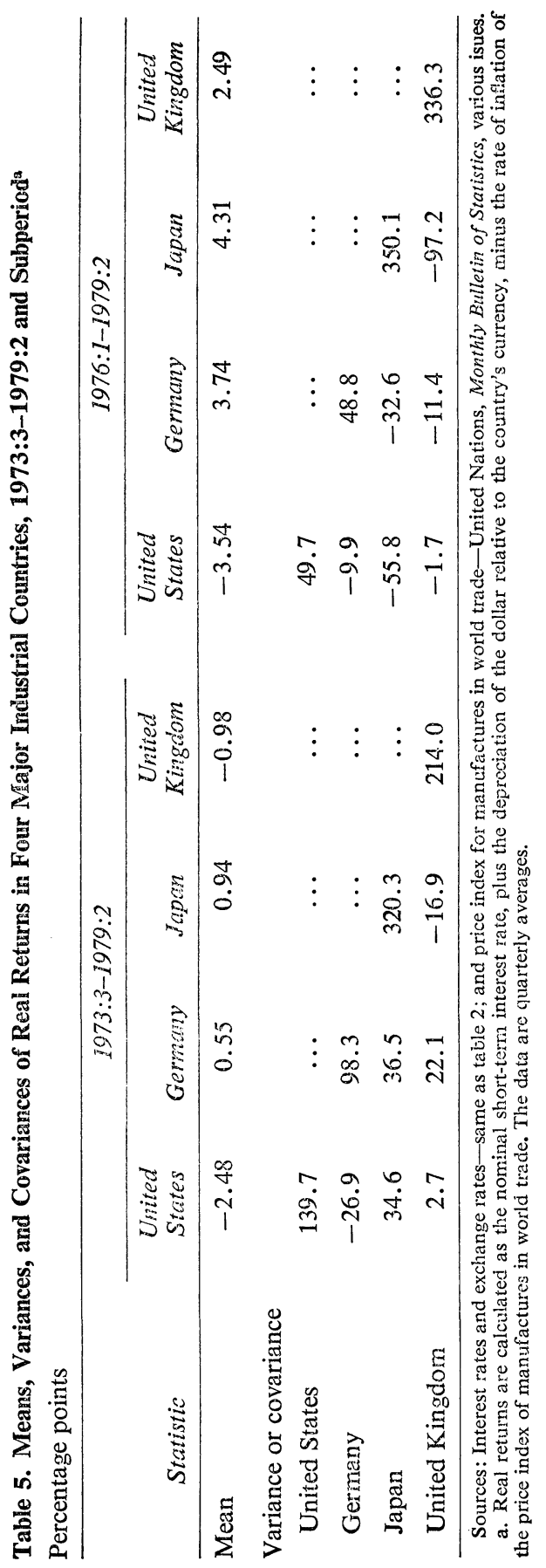


tial in mean real yields, is quite small because of the large variance of the nominal rate of depreciation that makes speculation risky. The share in the minimum variance portfolio is substantial, though, because the mark is an attractive asset-it has a relatively low variance of the real yield and a negative covariance with the dollar. The exercise, while merely an illustration, does suggest that the mark has characteristics that should make it play a large role in portfolios, and indeed, an even greater role as an international asset than was the case in the 1960s or early 1970s.

The argument may overstate the case in a number of ways. First, the realized returns may not equal the return distribution that investors anticipate. This is even more true if much of the differential in mean real returns reflects unanticipated mark appreciation. ${ }^{18}$ Second, other currencies may enter the portfolio, some with features more attractive than those of the mark. Third, international differences in consumption patterns may bias the portfolio shares away from those implied by the return distribution of table 5. Each of these arguments has some force, although none

$$
\bar{w}=w(1+\bar{r})+x w\left(\bar{r}^{*}-\bar{r}\right) ; \quad s_{\tilde{w}}^{2}=w^{2}\left[(1-x)^{2} s_{r}^{2}+x^{2} s_{r^{*}}^{2}+2 x(1-x) s_{r * *}\right],
$$

where a bar denotes a mean. Maximizing utility with respect to $x$ yields the optimal portfolio share,

$$
x=\frac{\left(\bar{r}^{*}-\bar{r}\right)+\theta\left(s_{r}^{2}-s_{r r^{*}}\right)}{\theta s_{n}^{2}},
$$

where $\theta \equiv-U_{2} w / U_{1}$ is the coefficient of relative risk aversion, $s_{r r *}$ is the covariance of real returns, and

$$
s_{n}^{2} \equiv s_{r}^{2}+s_{r^{*}}^{2}-2 s_{r *}
$$

is the variance of the nominal rate of depreciation. The first term, $\left(\bar{r}-\bar{r}^{*}\right) / \theta s_{n}^{2}$, corresponds to the speculative portfolio share in marks and depends on the mean real yield differential and the variance of the nominal rate of depreciation. The second term represents the hedging, or minimum-variance, portfolio that depends only on variances. For further discussion, see Rudiger Dornbusch, "Exchange Risk and the Macroeconomics of Exchange Rate Determination" (Massachusetts Institute of Technology, April 1980), and the references cited there.

18. Table 5 cannot strictly be used to establish the case for diversification since the data reflect both the "fundamentals" and the effect of the alleged portfolio diversification. To the extent that the incidence of the latter was unanticipated, the reported means and variance are not those the asset holders had in mind and accordingly cannot be used to establish the case for portfolio diversification. In a short time-series for the flexible exchange rate system there is no apparent way of extracting the fundamentals, nor is it possible to tell how serious the discrepancy has been between previous beliefs and ex post returns. 
of them necessarily suggests a lower mark share in an international portfolio. ${ }^{19}$

The main point is simply that the transition to flexible rates has quite decisively changed the structure of real returns confronting international investors-central banks, firms, or households. With the new return structure, and by virtue of size, the mark should occupy a large share of portfolios, much larger than would have been expected in 1970-73, before the period of flexible exchange rates. Investors can be expected to make a gradual transition to the new diversification pattern. But, as the poorly understood process of substitution from $\mathrm{M}_{1}$ to negotiable-orders-of-withdrawal (NOW) accounts and money-market funds in the United States suggests, little is known about the dynamics of portfolio adjustment.

As the substitution process takes place, the mark will tend to appreciate unless there is an offsetting increase in the relative supply of assets denominated in marks. Such an increase could be created through deficit finance, arising from sterilized exchange rate intervention, or take the form of Carter bonds (bonds issued by the U.S. government denominated in marks). In fact, as I show below, there has been a large increase in the relative supply of these assets because of larger German deficits. Sterilized intervention has made up a further part of the increased demand. The remainder has been met by appreciation of the mark, revaluing the share of marks already existing in international portfolios.

A first implication of the portfolio model then is to help identify a shortage of marks. The adjustment process to the new role of the mark as an international asset has brought about a curious reversal of the old intermediation view of the U.S. balance of payments. Germany has been showing a sustained short-term capital account surplus with a direct investment and portfolio investment deficit. Germany displays the pattern typical of the United States when the dollar took an increasing role in international portfolios after the restoration of currency convertibility in the late 1950 s.

19. Kouri and Macedo found an optimal mark share of 37 percent in a multiplecurrency portfolio with local habitats. See their "Exchange Rates and the International Adjustment Process," p. 129. See, too, the analysis in William Fellner, "The Bearing of Risk Aversion on Movements of Spot and Forward Exchange Relative to the Dollar," in John S. Chipman and Charles P. Kindleberger, eds., Flexible Exchange Rates and the Balance of Payments: Essays in Memory of Egon Sohmen (Amsterdam: North-Holland, forthcoming). 
RELATIVE ASSET SUP PLIES, WEALTH, AND EXCHANGE RATES

I now explore the portfolio model further to see whether there are implications that reinforce or put in question the conjecture discussed above: that for given asset supplies and wealth the structure of real returns implies a shift in portfolios toward assets denominated in marks, thus explaining the persistent appreciation of the mark.

The portfolio-diversification model implies a relationship between the nominal interest differential, the expected rate of depreciation, and the risk premium, $R$ :

where

$$
\dot{e}=i-i^{*}+R\left(\frac{E V^{*}}{V+E V^{*}}, \frac{W^{*}}{W+W^{*}}\right),
$$

$E=$ level of domestic currency price of foreign exchange

$W=$ level of wealth

$V=$ supply of nominal debt.

The risk premium in equation 6 is an increasing function of the relative supply of assets denominated in foreign currency, $E V^{*} /\left(V+E V^{*}\right)$, and a decreasing function of foreign relative wealth. ${ }^{20}$ What matters for the risk premium are the relative supplies of outside bonds (net assets of the private sector) denominated in the two currencies, independently of the issuing source. ${ }^{21}$ Risk is here a question of the variability of real returns due to uncertain inflation and exchange rate depreciation, not a

20. The risk premium can be written as

$$
R=\theta\left[s_{n}^{2}\left(\frac{E V^{*}}{V+E V^{*}}-\beta\right)-s_{q}^{*}\left(\phi-\phi^{*}\right) \frac{W^{*}}{W+W^{*}}\right],
$$

where $V$ is domestic currency outside bonds, and $W$ is domestic nominal wealth; $s_{n}^{2}$ and $s_{q}^{2}$ are the variances of the rates of nominal and real depreciation; $\theta$ is the coefficient of relative risk aversion; $\phi-\phi^{*} \geq 0$ equals the difference between domestic and foreign expenditure shares of domestic goods; and $\beta$ is the minimum-variance portfolio share defined in note 17. For a derivation, see Dornbusch, "Exchange Risk."

21. Frankel and Kouri emphasized that the risk premium involves outside assets independent of the issuer. See Jeffrey A. Frankel, "The Diversifiability of Exchange Risk," Journal of International Economics, vol. 9 (August 1979), pp. 379-93; and Pentti J. K. Kouri, "The Determinants of the Forward Premium," Seminar Paper 62 (University of Stockholm, Institute for International Economic Studies, August 1976). 
question of default. Note also that the relative wealth term will give rise to a risk premium only to the extent that there are differences in consumption patterns and that there is variability in the real exchange rate.

Suppose now that interest rates and anticipated rates of depreciation are given, perhaps determined by, the monetary sector of the more general model. The risk-premium model has implications for the relationships among wealth, asset supplies, and the exchange rate. In particular, the model implies that an increase in foreign relative wealth, say arising through a cumulative foreign current account surplus, will bring a relative increase in the demand for securities denominated in foreign currency. The resulting disequilibrium in the asset market is resolved by an appreciation of the foreign currency that revalues existing stocks of securities denominated in foreign currency. This must be an unanticipated wealth redistribution; otherwise, speculators would have anticipated the jump in the exchange rate.

Unanticipated changes in the relative supplies of securities likewise affect the exchange rate. For example, an unanticipated fiscal deficit that expands the supply of bonds denominated in foreign currency leads to a depreciation of the foreign currency, which restores portfolio balance at unchanged yields. (In general, exchange rates and asset yields are jointly determined.)

The risk-premium model has served as the basis for extensive research attempting to explain exchange rate movements by changes in relative wealth (using changes in net foreign assets as a proxy) and in relative asset supplies. ${ }^{22}$

The model has had mixed results in empirical tests, largely because of the difficulty in developing measures of relative nominal outside assets and relative nominal wealth. Part of the problem may also have been the use of actual versus unanticipated variables. Given these difficulties, the existing results must be considered very tentative. Even so, the risk-premium model is of interest because it offers, through the wealth channel, a role for the current account to affect exchange rates. At the same time, this

22. Early work, in particular Branson, Halttunen, and Masson, "Exchange Rates in the Short Run," gave particular emphasis to the current account, taking wealth to be represented by the cumulative current account. A more balanced treatment that recognizes the central role of asset supplies, as opposed to the distribution effects induced by current account imbalances, is found in Obstfeld, "Capital Mobility," and John P. Martin and Paul R. Masson, "Exchange Rates and Portfolio Balance," Working Paper 377 (National Bureau of Economic Research, August 1979). 
Table 6. Current Account Balances and Net Borrowing in Germany, and Ratios of German to U.S. Debt, 1973-79

Billions of deutsche marks, except as noted

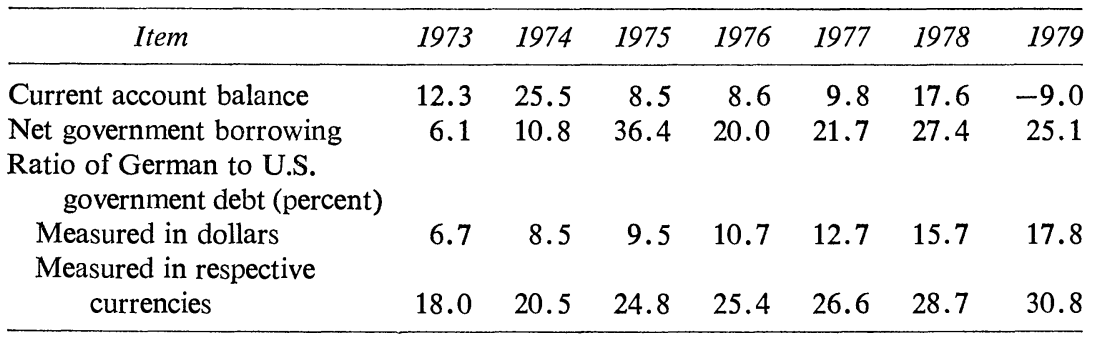

Sources: Government debt and borrowing-International Monetary Fund, International Financial Statistics, vol. 33 (May 1980), series ae, series 84 and 88, and series 88, pp. 164, 166, and 404, respectively; and current account balances-Deutsche Bundesbank, Monthly Report of the Deutsche Bundesbank, vol. 32 (March 1980), p. 70.

model introduces a potential link between deficit finance and exchange rates through the relative supply of assets. It thus supplements the extended Mundell-Fleming model and offers alternative channels through which current account and fiscal innovations can affect the exchange rate. Indeed, the equations reported in tables 3 and 4 may well reflect in part the effects of the risk-premium model.

\section{MARK APPRECIATION}

The risk-premium model may help explain the mark appreciation of recent years. In table 6, I report the German current account balance, net public sector borrowing, and the ratio of German to U.S. debt (valued both in dollars and in the respective currencies). The first point to note is that since 1975 the current account has been entirely dominated by the fiscal deficit. The demand for mark assets created by the redistribution of wealth toward Germany through the current account must have been met quite amply by the deficit finance. The German debt has increased much more rapidly than that of the United States. Thus if a risk-premium view were taken, one would expect the mark to show a cumulative depreciation, not an appreciation.

The risk-premium model suggests that a demand shift toward assets denominated in marks has dominated the downward pressure on the exchange rate arising from the combination of changes in relative wealth and the relative supplies of mark assets. Given the attempt to attain 
optimal diversification, the mark was appreciating because of an insufficient creation of mark assets. ${ }^{23}$

The risk-premium model has one further implication that has relevance for the equations in tables 3 and 4 . The existence of a risk premium implies that not all the difference between interest differentials and actual depreciation is unanticipated; part corresponds to the risk premium and only the residual represents news. Thus equation 4 becomes

$$
\begin{aligned}
\dot{e}^{\prime}-\left(i-i^{*}\right) & =\left(\dot{e}^{\prime}-\dot{e}\right)+R, \\
& =\text { news }+ \text { risk premium. }
\end{aligned}
$$

The risk premium accordingly can account for a significant constant or for serial correlation in the equations above. ${ }^{24}$

\section{The Flexible Exchange Rate System}

I now examine some key features of the system of flexible exchange rates to form a judgment about its shortcomings and the possibilities for reform. Has the system been critically defective? In this section I investigate some firmly established working characteristics of the system, including intervention, interest rate policies, current account adjustment, and current account financing. The issues are whether intervention policies have been designed to frustrate real exchange rate adjustment; whether interest rate policies were significantly restricted by actual or potential exchange rate developments; and finally, whether current account imbalances have been sustained and officially funded rather than adjusted and financed through capital flows. ${ }^{25}$

23. The data in table 6 understate the increase in these assets because they omit items such as Carter bonds or debt created through sterilized intervention.

24. Cumby and Obstfeld do find evidence of a risk premium in weekly data for all major currencies. See Robert E. Cumby and Maurice Obstfeld, "Exchange-Rate Expectations and Nominal Interest Differentials: A Test of the Fisher Hypothesis," Discussion Paper 34 (Columbia University, Department of Economics, July 1979).

25. For an extensive discussion see the papers by Jacques R. Artus and John H. Young, "Fixed and Flexible Exchange Rates: A Renewal of the Debate," IMF Staff Papers, vol. 26 (December 1979), pp. 654-98; Morris Goldstein, Have Flexible Exchange Rates Handicapped Macroeconomic Policy? Special Papers in International Economics, 14 (Princeton University, International Finance Section, June 1980); and Steven W. Kohlhagen, "The Experience with Floating: The 1973-1979 Dollar" (University of California at Berkeley, n.d.). 
I show that the capital mobility problem is summarized by the observation that when the current account gets bad the capital account gets worse. The reason is that interest rate policies are oriented toward internal balance, which aggravates the exchange rate consequences of cyclically unsynchronized movements in economic activity in the world economy.

\section{OFFICIAL INTERVENTION}

The reported changes in official reserve holdings have increased sharply during the 1970s. Have intervention policies had systematically stabilizing characteristics?

Figure 4 shows an adjusted series for changes in U.S. net liabilities to foreign official reserve agencies. The figure indicates sizable swings in intervention, which were larger than the swings in the U.S. current account. I present equations on the determinants of intervention in table 7. Given the size of reserve holdings and the level of nominal interest rates, much of the reported increase reflects the accrual of interest earnings rather than active market intervention. I thus use as a dependent variable an adjusted series that subtracts from changes in reserves an amount equal to the U.S. Treasury bill rate times the lagged stock of reserves. This series is measured as a fraction of lagged reserves. Equations 7-1 and 7-2 use unanticipated depreciation rates to explain U.S. net liabilities to foreign official holders. With a policy of "leaning against the wind," foreign central banks would acquire dollars through intervention whenever the dollar showed unanticipated depreciation. The equations strongly support that view, although only a small fraction of the variance is explained.

Equation 7-2 suggests that unanticipated depreciation of 1.0 percentage point (at an annual rate) leads to a cumulative intervention of 0.4 percent of foreign net claims on the United States, which at current levels of foreign net reserve holdings is about $\$ 600$ million. The constant term of 1.0 suggests that the absolute size of intervention is growing along with nominal reserve holdings.

Equation 7-3 considers German intervention policy. There is more evidence of leaning against the wind. Unanticipated depreciation of 1 percentage point, at an annual rate, leads to an intervention at 1979 reserve levels of about $\$ 140$ million. Interestingly, macroeconomic conditions affect the level of German intervention. A high rate of unemploy- 


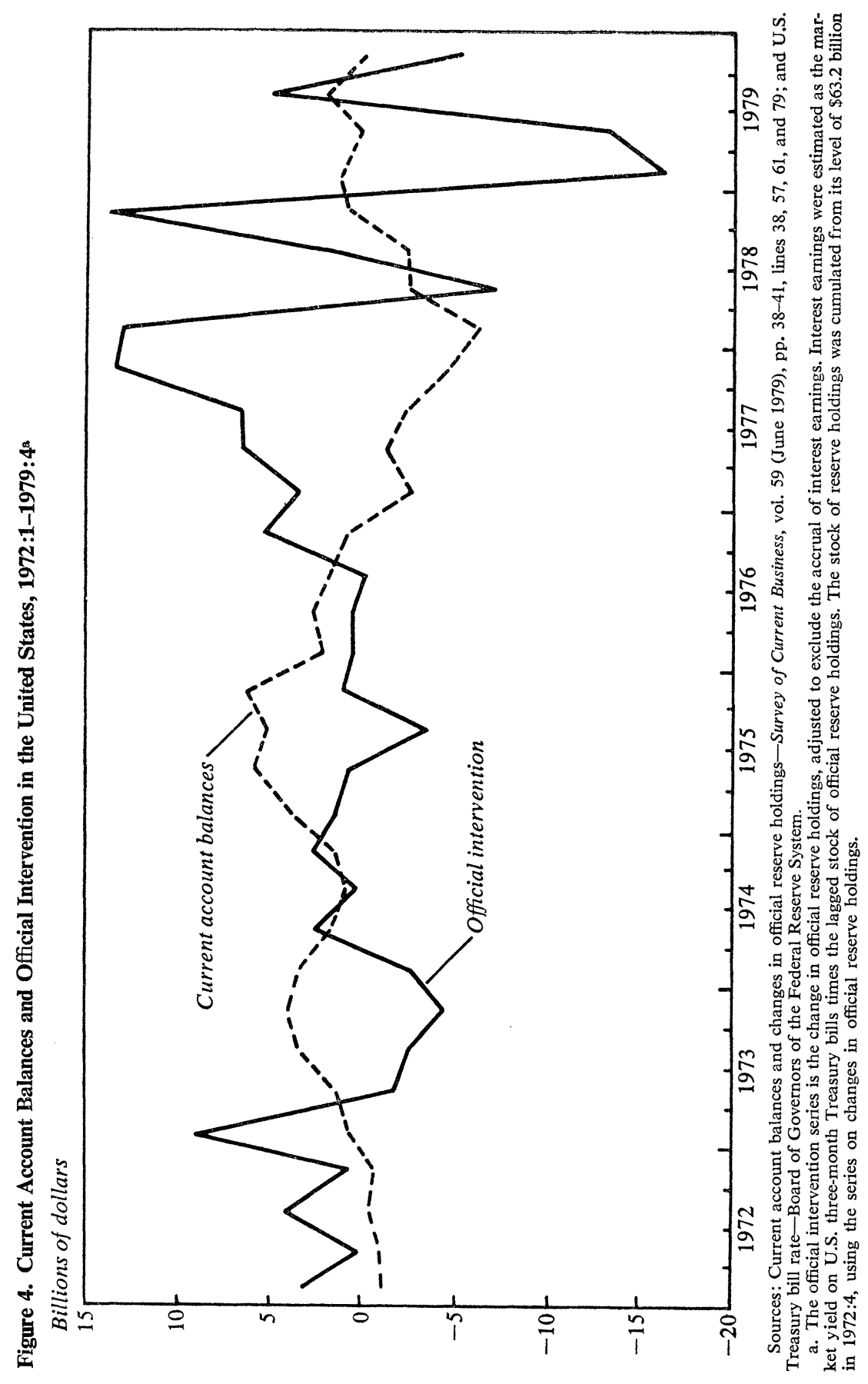




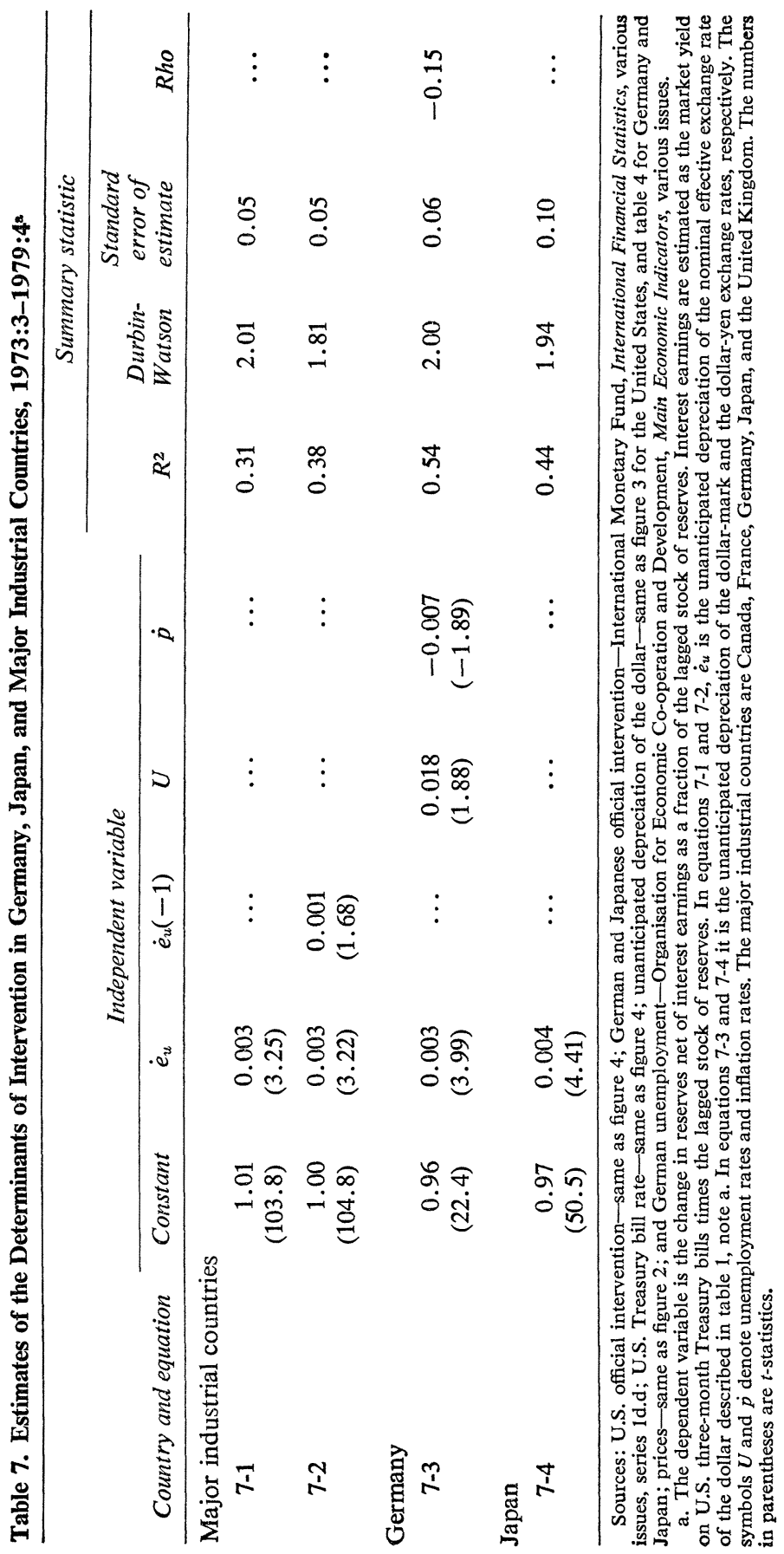


ment increases the rate of intervention, while high inflation reduces intervention. With more unemployment, authorities use intervention to slow down real dollar depreciation to achieve a "beggar-my-neighbor" effect. With faster inflation, unanticipated dollar depreciation is opposed less strongly in order to achieve a reduction in inflationary pressure or to avoid imported inflation. The coefficients on the cyclical variables suggest a policy that goes significantly beyond leaning against the wind. ${ }^{26} \mathrm{I}$ found no evidence of real exchange rate targets.

Equations of the form reported in table 7, which use unanticipated depreciation to explain reserves adjusted for interest earnings, are more successful than actual reserve changes and actual depreciation. This can be interpreted to mean that nominal interest payments roughly maintain the stock of real reserves in the face of dollar depreciation. Unanticipated depreciation as the explanatory variable is compatible with a PPP evolution of nominal exchange rates and with an adjustment of real exchange rates that is dampened, but not offset, by intervention.

There also is strong evidence of leaning against the wind in the equations for Japan. Unanticipated dollar depreciation again appears as the relevant determinant. The size of the reaction coefficient is similar to those reported for Germany and for the rest of the world. For Japan, however, there is no evidence of cyclical influences on intervention policy.

The intervention equations support the view that monetary authorities largely aimed their operations at smoothing unanticipated movements in the exchange rate. For Germany, the presence of cyclical variables also suggests an element of beggar-my-neighbor policy in exchange intervention.

26. On intervention policy and specifically "leaning against the wind" see Paul Wonnacott, "Exchange Stabilization in Canada, 1950-4: A Comment," Canadian Journal of Economics and Political Science, vol. 24 (May 1958), pp. 262-65; Paula A. Tosini, Leaning against the Wind: A Standard for Managed Floating, Princeton Essays in International Finance, 126 (Princeton University, International Finance Section, December 197 $\rightarrow$ Jacques R. Artus, "Exchange Rate Stability and Managed Floating: The Experience of the Federal Republic of Germany," IMF Staff Papers, vol. 23 (July 1976), pp. 312 $\rightarrow$ Peter J. Quirk, "Exchange Rate Policy in Japan: Leaning Against the Wind," IMF Staff Papers, vol. 24 (November 1977), pp. 642-64; David John Longworth, "Floating Exchange Rates: The Canadian Experience" (Ph.D. dissertation, Massachusetts Institute of Technology, 1979); and Stanley W. Black, "Central Bank Intervention and the Stability of Exchange Rates," Seminar Paper 136 (University of Stockholm, Institute for International Economic Studies, February 1980), 


\section{INTEREST RATE POLICIES}

The sensitivity of exchange rates to monetary policy interferes with the ability of monetary policy to achieve a noninflationary real expansion. Lowering interest rates leads to exchange rate depreciation and faster inflation through rising import prices. Exchange rate sensitivity thus steepens the Phillips curve when monetary policy is used to affect real output. It is not possible to determine whether the worsened trade-off has significantly reduced the use of monetary policy as an instrument. What can be investigated is whether interest rates have shown the cyclical pattern associated with domestic stabilization, declining during a recession and increasing with inflation. One can also ask whether exchange rate depreciation exerted a significant effect on interest rate policy.

Table 8 reports regression equations for the German-U.S. and Japanese-U.S. differential in short-term interest rates. The differential is used on the assumption that international cyclical movements have not been closely synchronized. The German-U.S. differential in nominal interest rates is explained by the current inflation differential, unemployment in the respective countries, and the lagged nominal interest rate differential. Higher inflation differentials are reflected in a higher nominal interest differential. An increase of 1 percentage point in the German unemployment rate leads to a decline of about 2 percentage points in the nominal interest differential. It cannot be established that the flexible rate system did not weaken the use of countercyclical monetary policy. But the evidence is that relative interest rates continued to have a clearly cyclical pattern.

In the German-U.S. case, I found no evidence for either monetary growth targets, intervention, or exchange depreciation as a significant influence on interest differentials. ${ }^{27}$

Equations 8-2 to 8-4, explaining the Japanese-U.S. interest rate differential, provide more evidence of a cyclically stabilizing pattern of nominal interest rates. Higher inflation differentials lead to higher nominal yield differentials. Higher unemployment in Japan reduces the relative Japanese interest rate, while higher unemployment in the United States raises it.

27. For further evidence see Jean Tirole, "Exchange Rate Expectations and Monetary Policy: A Structural Approach for France, Germany, U.K.” (Massachusetts Institute of Technology, n.d.). 


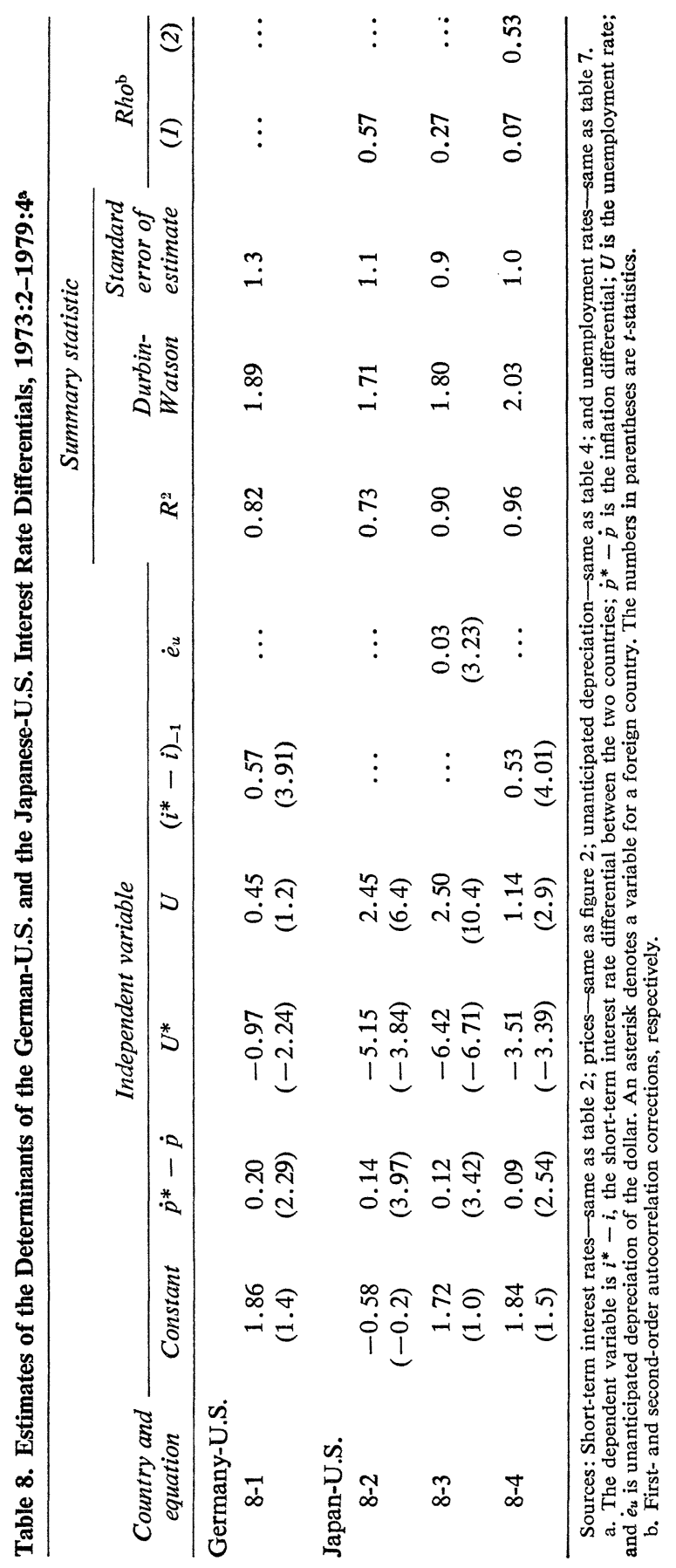


Unlike the German-U.S. case, the equations for Japan show high serial correlation of errors and are reported with rho corrections. Unanticipated depreciation is introduced in equation 8-3 and shows a significant coefficient but with the wrong sign-higher dollar depreciation leads to an increased spread in favor of Japan. The variable may represent joint errors in the interest and exchange rate equations; or it may merely pick up lagged adjustment effects, as equation 8-4 suggests.

From the interest rate evidence it seems apparent that, whatever limitations on monetary policy may exist, interest spreads internationally have had the cyclical pattern called for by stabilization objectives. To that extent, at least, there is no clear demonstration that the flexible exchange rate system has limited the use of instruments. Furthermore, there is no evidence that interest rates have been systematically affected by intervention or exchange rate targets.

\section{CURRENT ACCOUNT ADJUSTMENT AND CAPITAL FLOWS}

The next question is whether the flexible exchange rate period has been one of persistent and large current account imbalances with exchange rate movements exerting relatively little impact to restore balance. Table 9 shows means, standard deviations, and serial correlation of current accounts for four major industrial countries. The 1960-73 period of fixed exchange rates is compared with that of flexible exchange rates, 197379. No substantial change in current account behavior is apparent. Imbalances did not become more persistent, and, in particular, the United States did not have a persistent deficit.

The surprise of the last few years, if anything, is the fact that current account imbalances are not at all the "sticky mass" that Keynes thought they were. Instead, the large effect of variations on current accounts and the responsiveness of trade flows and direct investment to real exchange rates lead to a view of great flexibility in all important dimensions of the balance of payments.

How have current account imbalances been financed? In particular, to what extent have the large swings in current accounts been financed by stabilizing private capital flows? As figure 4 shows, exchange market intervention in the dollar, both transitory and cumulative, has been subtantial compared to current account imbalances, frequently exceeding the latter by a large margin. In fact, rather than financing those im- 
Table 9. Current Account Balances as a Percent of GNP for Four Industrial Countries, 1960-73 and 1973-79

Percentage points or correlation

\begin{tabular}{lccc}
\hline & \multicolumn{3}{c}{ Statistic } \\
\cline { 2 - 4 } Period and country & Mean & $\begin{array}{c}\text { Standard } \\
\text { deviation }\end{array}$ & $\begin{array}{c}\text { Serial } \\
\text { correlation }\end{array}$ \\
\hline 1960-73 & & & \\
United States & 0.4 & 0.4 & 0.58 \\
Germany & 0.7 & 0.9 & 0.41 \\
Japan & 0.5 & 1.2 & 0.39 \\
United Kingdom & \\
1973-79 & 0.1 & 1.1 & 0.37 \\
United States & & & \\
Germany & 0.1 & 0.6 & 0.28 \\
Japan & 1.0 & 0.9 & -0.11 \\
United Kingdom & 0.5 & 0.9 & 0.61 \\
(a) & -0.9 & 1.8 & 0.62 \\
\hline
\end{tabular}

Source: Organisation for Economic Co-operation and Development. a. The output measure is gross domestic product.

balances, net capital flows add to them. Deficits are accompanied by net capital outflows and surpluses by net inflows. In 1977 and 1978, for example, the United States ran current account deficits of about $\$ 14$ billion, while the holdings of foreign official reserve agencies increased by $\$ 35$ billion and $\$ 32$ billion, respectively. In net terms the foreign private sector's claims on the United States were reduced at a rate of more than twice as great as the U.S. deficit. In 1979, in turn, the U.S. current account was nearly balanced; central bank intervention, this time in support of foreign currencies, amounted to nearly $\$ 16$ billion.

It appears that interest rate policy, adjusted for depreciation, was not at all geared toward financing current account imbalances and stabilizing exchange rates. On the contrary, the independent pursuit of interest rate policy, together with current account surprises, has given rise to exchange rate instability, capital flows, and intervention. This has led to a clear positive relation between the U.S. current account and the return on U.S. assets, which is illustrated in figure 5. When the United States was in deficit, the return on dollar assets, adjusted for depreciation, was negative. Conversely, when the United States showed a surplus, the return differential, adjusted for depreciation, was positive.

A coherent story emerges from combining the evidence in figure 5 with that for intervention, exchange rate determination, and portfolio selection. 


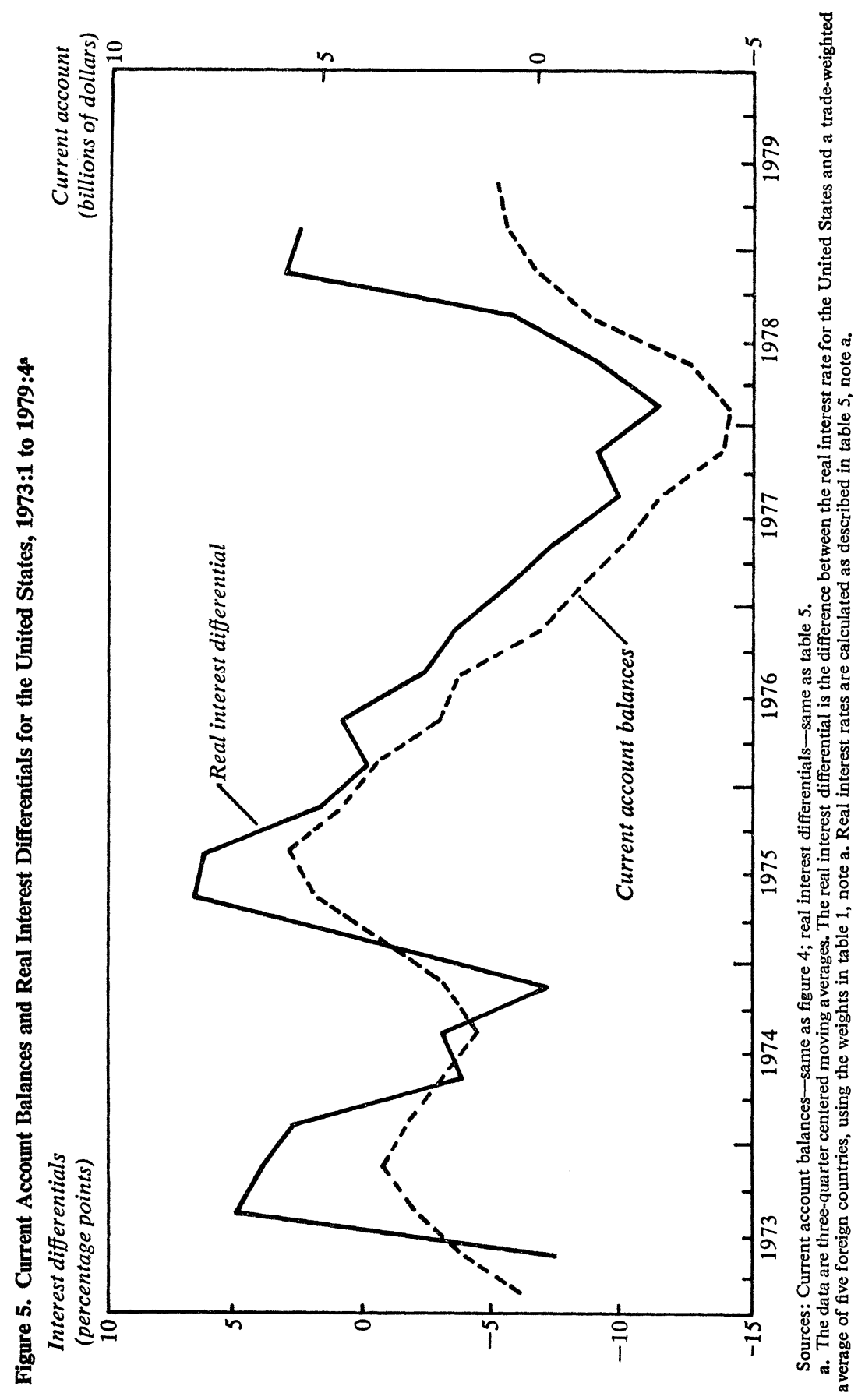


Current account surprises give rise to unanticipated fluctuations in the exchange rate. There is no offset through interest rate policy and, accordingly, real interest differentials worsen for the deficit country. The unanticipated depreciation leads central banks to intervene in support of the depreciating currency, and the adverse depreciation-adjusted interest differential leads portfolio holders to shift from the depreciating currency.

Central bank intervention provides the umbrella for portfolio holders to shift their portfolios in response to anticipated interest differentials. Sterilization of the intervention implies that central banks can largely pursue their interest rate policy, albeit at the cost of larger and more dramatic intervention operations.

\section{Exchange Rate Flexibility and the Capital Mobility Problem}

The preceding review of theory and empirical evidence indicates the fundamental problems that confront the design of an exchange rate and payments system. The system must meet conflicting needs. On the one hand, it should have flexible real exchange rates to provide for adjustment of current account imbalances through channels besides deflation or protection. On the other hand, short-term disturbances in the real sector should be largely accommodated at unchanging real exchange rates so that unnecessary variability will not be introduced in the allocation of resources. This accommodation requires a mechanism that ensures the financing of current account imbalances, cyclical or otherwise, through capital flows. Furthermore, financial disturbances should be substantially accommodated through asset management-trading one debt for another-and should not affect real activity or the real exchange rate. This requires institutional arrangements that make possible largescale sterilized intervention or the issuance of debt denominated in foreign currency.

In the 1960s governments opted for an exchange rate regime with fixed nominal exchange rates, full accommodation of financial disturbances through pegging of exchange rates, and a lack of effective mediumterm adjustment in the real exchange rate. When the dollar became overvalued under this regime, it led to the collapse of the system of fixed exchange rates and has left observers with the impression that a flexible real exchange rate is an essential part of a viable exchange and payments 
system. The large disparity of current inflation rates among countries and the imprecision in estimating their respective underlying trend rates of inflation make it difficult to formulate viable rules for pegging nominal rates, even if there could be agreement on the appropriate real exchange rate.

Once it is accepted that the medium-term real exchange rate should be flexible and that tight pegging of nominal rates is infeasible, the range of options is reduced to a form of floating rates. There does remain, however, a dimension of choice that may add to the stability of the macroeconomy and that concerns the treatment of capital flows. Should capital be free to move in response to expected yields and risks, or should it be immobilized? James Tobin has summarized one main concern about complete freedom of capital movements:

Under either exchange rate regime the currency exchanges transmit disturbances originating in international financial markets. National economies and national governments are not capable of adjusting to massive movements of funds across the foreign exchanges, without real hardship and without significant sacrifice of the objectives of national economic policy with respect to employment, output, and inflation. ${ }^{28}$

Tobin proposes "to throw some sand in the wheels of our excessively efficient international money markets." ${ }^{29}$ Specifically, he advocates placing an internationally agreed, uniform, proportional tax on all spot conversions of one currency into another. The tax would reduce the round trip return on international portfolio shifts, and thereby open up an interest spread that would leave monetary authorities more freedom. The proposal would virtually eliminate short-term capital flows and allow the basic balance, in conjunction with intervention, to determine the exchange rate. Relieved of the need to cope with massive short-term capital flows, interest rate policy would be freer to address domestic objectives, and exchange rates would presumably be more stable.

The Tobin tax proposal presumes that the failure of private short-term capital flows to finance current accounts adds to exchange market instability and to the need to intervene. Although capital flows have largely failed to play a financing role, they have forced major changes in real exchange rates whenever government policies failed to aim for cyclical

28. James Tobin, "A Proposal for International Monetary Reform," Cowles Foundation Discussion Paper 506 (Yale University, October 1978), p. 3.

29. Ibid. 
coordination and a dampening of external imbalances. Thus capital flows definitely promoted current account adjustment, although possibly exaggerating exchange rate instability.

It is not certain in what way the Tobin tax would work to stabilize exchange rates. There would be less incentive to move capital internationally in response to small yield differentials; but then the basic balance and the extent of central bank intervention would govern the exchange rate. Rather than leaning against the wind, central banks would have to take a view of exchange rates and become rate setters. Would they want to maintain nominal exchange rates or would they adjust real exchange rates in response to current account imbalances?

There is a second, and perhaps more serious, objection to the proposal. Suppose a country does not have the reserves to finance a transitory current account imbalance and thus wishes to use interest rate policy to attract capital. Clearly such a country would now have to increase interest rates by more than it would in the absence of the tax. The country would suffer the burden of financing the deficit and the Tobin tax. There is, of course, an alternative. The country could bring about a sufficiently large depreciation that the expectation of future depreciation would be reduced or eliminated; then with unchanged interest rates there would be a sufficient expected yield differential to attract capital inflows. But again, the country would be paying for the "sand in the wheels." 30

The welfare economics of the Tobin proposal is not without question. From the standpoint of utility maximization, the choice of an optimal portfolio ranks on a par with the ability to choose one's preferred diet. To the extent that the portfolio cannot be efficiently diversified solely from home securities-and this would surely be the case for small countries-the tax is as disturbing an intervention as a tariff.

Once the principle of free capital flows is accepted, there remains the issue of how to live with them. Capital flows should operate in a stabiliz-

30. While I argue against the Tobin tax in its worldwide application, I do think there is a forceful case for the tax in isolated instances. I particularly note the example of the United Kingdom, where the differential adjustment speed of interest rates and inflation, in response to the stabilization policy, has led to a vast real appreciation. A real interest equalization tax is warranted to repel capital inflows and thus maintain a more nearly constant real exchange rate in the adjustment of prices to lower inflation. For a further discussion see Nissan Liviatan, "Neutral Monetary Policy and the Capital Import Tax" (Hebrew University, October 1979); and Dornbusch, Open Economy Macroeconomics, chap. 12. 
ing manner to finance transitory current account imbalances while allowing real exchange rate changes to cope with medium-term adjustment in the current account balance. It is, in fact, not possible to identify what part of a current account balance it is appropriate to finance and what part requires adjustment. The proper policy rule for stabilizing real exchange rates when confronted with short-term and financial disturbances, without affecting the medium-term adjustment of real rates, is the following: a country with a growing current account deficit (particularly one that occurs in the process of unsynchronized cyclical movements) would both raise its real interest rate and intervene by leaning against the wind. The analysis of the present paper shows that only half the rule has, in fact, been pursued: intervention policy has leaned against the wind, but interest rate policy has been the opposite of what is recommended here.

What are the policy choices that are likely to induce more stable capital flows? It is easy to identify three different areas for reform. The first concerns policies to ease the adjustment process of an international portfolio shift from dollars to marks. That process is under way, and failure to recognize the portfolio substitution will lead to unnecessary variability in exchange rates and changes in the real exchange rates. Portfolio substitution implies a major problem for stabilization policy because its dynamics are not clear. Using sterilized intervention to cope with portfolio shifts has been an appropriate pragmatic response. Two alternatives are reshuffling more directly the currency denomination of the existing stocks of outside assets, and issuing indexed debt.

The second reform is to use monetary policy deliberately to induce stabilizing capital flows. When unanticipated, transitory disturbances arise in the current account, interest rates should be adjusted to avoid excessive real exchange rate movements. That, of course, will leave less room for domestic activism or will force the question of creating a better policy mix for domestic objectives.

The third, and perhaps the most important reform, draws on the evidence that exchange rate movements largely reflect adjustments to unanticipated current account and cyclical disturbances. This suggests that efforts to create a more predictable policy environment may well make a contribution to stabilizing exchange rates. 


\section{Comments by William H. Branson}

The decade since the first meeting of the Brookings panel has witnessed a complete revolution in thinking about exchange rate determination, a radical change in the portfolio problem facing international investors, both private and public, and a real depreciation of the dollar exchange rate by approximately 25 percent. Rudiger Dornbusch's paper gives an interesting and accurate account of the development of theorizing and the current state of empirical evidence on exchange rates, integrates this with recent work on portfolio diversification, and then uses this analytical framework to discover a deutsche mark shortage to begin the 1980s. I generally agree with his views on these matters, so I have no slashing criticism to make. However, I would look at exchange rate theories from a different perspective.

\section{Exchange Rate Theories}

Dornbusch reviews the evolution of theories of exchange rate determination since 1973 or so, and cites empirical evidence that generally supports the portfolio-balance model. One way to view Dornbusch's account is as autobiography. It accurately describes the evolution of his thinking about exchange rates as he moved from Dornbusch 1974 vintage, ${ }^{1}$ a monetary-PPP (purchasing power parity) model, to 1980 vintage, a portfolio-balance model. His account of the development of theory is a logical progression from the most restrictive to the least restrictive, and he relaxes assumptions as he goes along. In this respect, his paper is

1. See Rudiger Dornbusch, "Capital Mobility, Flexible Exchange Rates and Macroeconomic Equilibrium," in E. Claassen and P. Salin, eds., Recent Issues in International Monetary Economics, Studies in Monetary Economics, vol. 2 (Amsterdam: North-Holland, 1976), pp. 261-78. The book is a collection of papers presented at a conference held in Paris in 1974. 
similar to Marina Whitman's 1975 BPEA paper on "global monetarism," and I propose the same alternative that I did in commenting on that paper: begin with the most general framework of an asset markets model and then narrow it down with additional assumptions as appropriate.

As I noted in my 1975 comments, a portfolio model can be reduced to a monetary model by eliminating the nonmoney assets from the analysis. This is done by assuming perfect substitutability between domestic and foreign assets, or by small-country assumptions that make interest rates exogenous. The additional simplification that leads to a monetary-PPP model is to assume perfect substitutability among goods, so the exchange rate is simply the ratio of two price levels.

Dornbusch's review begins with this model, which he labels the monetary approach. The exchange rate in this model follows the path of the two relevant price levels, which in turn are driven by excess demands for money in the two countries. This is the hyperinflation model in Jacob Frenkel's 1980 article; it is also Dornbusch vintage 1974. The present paper shows that the monetary-PPP model will not hold because PPP has not held. The 1970s have been a period of large movements in exchange rates vis-à-vis relative price levels due to a combination of real disturbances and initial portfolio disequilibria. ${ }^{2}$

The next model reviewed eliminates the assumption of short-run PPP, but retains perfect substitutability between foreign and domestic interestbearing assets, so the focus is still on money demand and supply. Wealth effects are still excluded from money demand. This is Dornbusch vintage $1976 .^{3}$ This extended Mundell-Fleming model does not permit different reactions of exchange rates to demand expansions that originate at home or abroad. The former should lead to a current account deficit and depreciation; the latter, to a surplus and appreciation. To bring the current account into the story, Dornbusch next introduces wealth effects, with increases in wealth coming from the current account and raising the demand for home goods relative to foreign goods. This is Dornbusch vintage $1978 .{ }^{4}$

2. For a review of the reincarnation of PPP in the 1970s and its subsequent demise, see Louka T. Katseli-Papaefstratiou, The Reemergence of the Purchasing Power Parity Doctrine in the 1970's, Special Papers in International Economics, 13 (Princeton University, International Finance Section, December 1979).

3. Rudiger Dornbusch, "Expectations and Exchange Rate Dynamics," Journal of Political Economy, vol. 84 (December 1976), pp. 1161-76.

4. Rudiger Dornbusch and Stanley Fischer, "Exchange Rates and the Current Account," American Economic Review (forthcoming in December 1980). 
The Dornbusch-Fisher model has an uncertain payoff, though. Demand expansion at home still leads to appreciation of the exchange rate, an "uncomfortable" implication. This is, after all, the original implication of Robert Mundell's analysis of fiscal expansion with "perfect capital mobility." Fiscal expansion raises the interest rate, causing an infinitely large capital inflow and exchange appreciation. The evidence, however, is that assets have sufficiently low substitutability that the opposite is the case in Japan and in the United States, with Canada a borderline case. ${ }^{5}$ At this point in Dornbusch's paper, however, with perfect substitutability the only way to obtain the "normal" results of demand expansion for Japan and the United States is to assume that it is accompanied by monetary accommodation.

This part of the paper makes me feel a bit uneasy. While the two models are important parts of the development of the literature, especially Dornbusch vintage 1976, their role here seems mainly to fill the space between vintage 1974 and vintage 1980, to be discussed below. The 1978 model is a modification of 1976 , to add the current account to the story, and it needs a monetary accommodation proviso to fit the stylized facts. It is also rendered obsolescent by the 1980 model.

This most recent vintage is discussed after the empirical section on testing "news." These results confirm the portfolio-balance model-Dornbusch 1980-so I will also discuss them below. With his discussion of portfolio diversification, Dornbusch finishes his review of exchange rate models by considering the portfolio-balance model with imperfect substitution between home and foreign assets in portfolio demands. In this model the current account affects the exchange rate by influencing portfolio composition as well as wealth. An increase in domestic demand generates a deficit in the current account and reduces the proportion of foreign assets in the portfolio. This increases excess demand for foreign assets and brings a depreciation of the exchange rate. The model is also consistent with portfolio diversification across currencies.

5. See Akihiro Amano, "Flexible Exchange Rates and the Macroeconomic Management: A Study of the Japanese Experience in 1973-78" (Kobe University, 1979); William H. Branson, discussion of Sung Y. Kwack and George R. Schink, "A Disaggregated Quarterly Model of United States Trade and Capital Flows: Simulation and Tests of Policy Effectiveness," in Gary Fromm and Lawrence R. Klein, eds., The Brookings Model: Perspective and Recent Developments (Amsterdam: NorthHolland, 1975), pp. 169-73; and John Helliwell, "Adjustment under Fixed and Flexible Exchange Rates," in Peter B. Kenen, ed., International Trade and Finance: Frontiers for Research (Cambridge: Cambridge University Press, 1975), pp. 379-410. 
I now return to the position of my 1975 comment on the Whitman paper. In all these models except the strict PPP approach, the proximate determinants of exchange rates are equilibrium conditions for asset markets. Exchange rates are determined in financial markets in the same sense as interest rates are. The most general asset market model is the portfolio-balance model with wealth effects and imperfect substitutability of home and foreign assets. One form of this model appears in my previous work. ${ }^{6}$ This model can be simplified by assuming perfect substitutability or price-taking behavior but retaining wealth effects to obtain the form of Pentti Kouri's 1976 model and the Dornbusch-Fisher model. Further elimination of wealth effects yields Dornbusch's monetary-approach model. If a PPP explanation of the exchange rate is imposed, the 1974 models of Frenkel and Dornbusch result. The literature developed over time from different initial views of exchange rate determination, but seems to be converging to the portfolio-balance model.

\section{Empirical Evidence on Exchange Rates}

The empirical evidence supports this convergence. The monetary-PPP model founders on the assumption of PPP, which may hold in the long run in the absence of real disturbances, or in a hyperinflation, but did not hold during the decade of the 1970s. There now is ample evidence that the current account matters for exchange rate adjustment. Evidence for the dollar-mark rate was presented in the 1976 paper by Jacques Artus, and some initial results for the other major currencies were reported by Branson and Halttunen. ${ }^{7}$ These, and other studies that Dornbusch cites, generally used actual instead of unanticipated variables. The equations

6. William H. Branson, "Asset Markets and Relative Prices in Exchange Rate Determination," Seminar Paper 66 (University of Stockholm, Institute for International Economic Studies, 1976); William H. Branson, Hannu Halttunen, and Paul Masson, "Exchange Rates in the Short Run: The Dollar-Deutschemark Rate," European Economic Review, vol. 10 (December 1977), pp. 303-24. For a complete exposition see Polly R. Allen and Peter B. Kenen, Asset Markets, Exchange Rates, and Economic Integration (Cambridge: Cambridge University Press, 1980).

7. William H. Branson and Hannu Halttunen, "Asset-market Determination of Exchange Rates: Initial Empirical and Policy Results," in John P. Martin and Alasdair Smith, eds., Trade and Payments Adjustment under Flexible Exchange Rates (London: MacMillan for Trade Policy Research Center, 1979), pp. 55-85. 
that Dornbusch reports in table 3 confirm the broad conclusion from the previous studies.

If the risk-premium equation 6 is combined with the estimating equation of table 3 , an equation is obtained for unanticipated depreciation that has on the right-hand side both the current account surprise and the risk premium. The latter is an increasing function of the stock of foreign assets, as shown in equation 6 . The current account surprise alters the stock of foreign assets. Thus the results in table 3 could reflect the effect of changes in foreign asset supplies on the risk premium, rather than the effects of current account news. I doubt that this bias is important, however. It should also be noted that it is hard to obtain empirical verification of equation 6 itself. In summary, the evidence is accumulating that the current account matters: surplus countries appreciate, and deficit countries depreciate. If the major industrial countries are arrayed from the ones with the largest surplus to the largest deficit, that array provides a good prediction of the rank order of appreciation and depreciation. ${ }^{8}$

This evidence is consistent with a portfolio-balance model including imperfect substitution, and with a monetary model having wealth effects. In his section on portfolio diversification and the mark, Dornbusch cites literature on portfolio diversification across currencies as evidence that supports the portfolio-balance model. In table 5 Dornbusch presents the variance-covariance structure on real returns for a cosmopolitan consumer-investor on short-term assets denominated in dollars, deutsche marks, yen, and pounds sterling. The low and frequently negative covariances of real returns clearly suggest imperfect substitutability.

\section{Portfolio Diversification}

In the section on portfolio diversification Dornbusch provides an analytical definition of the meaning of the term "dollar overhang" and shows how this might be quantified. Optimal portfolio combinations among currencies can be computed from a vector of expected real returns and a matrix of expected covariances around those real returns. The optimal portfolio is a linear combination of a minimum-variance portfolio and a

8. See Louka T. Katseli-Papaefstratiou, "The Transition to Flexible Exchange Rates," World Politics (forthcoming in December 1980). 
zero-net-worth speculative portfolio in which one borrows in some currencies and lends in others to obtain a preferred risk-return combination. An important element of the covariance matrix in many of these calculations is the negative covariance of the mark and the dollar, which gives both a large positive weight in the minimum-variance portfolio. Dornbusch provides an illustrative two-asset portfolio that is 50 percent marks and 50 percent dollars. The proportions for the mark and the dollar in the minimum-variance five-currency portfolio of Pentti Kouri and Jorge de Macedo are 33 percent and 59 percent, respectively, using a 1973-77 variance-covariance matrix. Using a 1973-78 matrix, Macedo presents portfolios for eight currencies under various assumptions concerning the weights for investors' optimal price indexes; there the proportion in marks is 14 percent and in dollars, 34 percent. $^{9}$ The results suggest that, from 1979 on, an optimum minimum-variance portfolio might contain dollars in the range of 35 to 45 percent, and marks in the range of 20 to 30 percent.

These proportions can be compared with the actual holdings of central banks. At the end of 1978, the central banks in the aggregate held special drawing rights of 167.9 billion in dollars ( 82.7 percent), 21.2 billion in marks (10.4 percent), and 14.1 billion in other currencies ( 6.9 percent)..$^{10}$ If central banks were conservative minimum-variance investors with currency preferences similar to the private sector, these approximate proportions suggest that the desired holdings would be SDR of about 80 billion in dollars (or 40 percent) and 50 billion in marks (or 25 percent). This official market "overhang" of an SDR excess supply of 90 billion in dollars and an SDR excess demand of 30 billion in marks presumably puts persistent downward pressure on the dollar and upward pressure on the mark, as Dornbusch notes.

An important feature of the optimal portfolio literature is the negative entries that come from positive covariances. In the Kouri-Macedo minimum-variance portfolio, for example, the yen and French franc have net liability positions. This would probably make the portfolio proportions

9. See Pentti J. K. Kouri and Jorge Braga de Macedo, "Exchange Rates and the International Adjustment Process," $B P E A, 1: 1978$, p. 129; and Jorge Braga de Macedo, "Portfolio Diversification Across Currencies," Discussion Paper 321 (Yale University, Economic Growth Center, September 1979), p. 40.

10. Data are from Beth F. Cobert, "An International Monetary Fund Substitution Account: The Proposal and tIs Prospects" (Princeton University, Senior thesis, 1980), table 8. 
arising from unconstrained optimization calculations inappropriate for official reserve holders, although they might still suggest currencies for borrowing by less developed countries. Thus the optimal portfolio literature would at best be a guide to the direction in which SDR weights should be adjusted to make it a more attractive investment instrument. In fact, such an adjustment seems to be in the proposal emanating from the April meeting in Hamburg of the International Monetary Fund's Interim Committee to reweight the SDR along the line of the Kouri-Macedo value weights. This reweighting would have made the investment aspect of the substitution account more attractive. The substitution account, in turn, could have helped to eliminate the excess supply of dollars in official hands. It is unfortunate that agreement could not be reached in Hamburg on the substitution account.

\section{External Adjustment Policy}

I have little to add to Dornbusch's discussion of intervention and exchange rate policy. "Leaning against the wind" in exchange market intervention, slowing the movement of the exchange rate in either direction, was a phenomenon that was noticeable as early as $1975 .{ }^{11}$ Dornbusch documents this for Germany and Japan; the same pattern of behavior can be observed for the United Kingdom and Canada, and other countries. The reaction function for Germany in my paper with Hannu Halttunen and Paul Masson on the dollar-mark exchange rate also illustrates leaning against the wind.

I think it may also be important to disaggregate long-term and shortterm capital for current account adjustment and capital flows. I am not sure I agree with Dornbusch's conclusion about stability of the current account balance, but it is clear that net long-term capital movements and the basic balance (the sum of the current account and long-term capital flows) have become less stable since 1970, as shown in table 1 . The table shows a large change in the current account in 1975 and 1977; another swing came in 1979. Long-term capital shows a big increase in instability

11. See William H. Branson, "Leaning Against the Wind' as Exchange Rate Policy" (Geneva: Graduate Institute of International Studies, 1976). The general pattern of intervention is discussed in a review of 1965-79 in William H. Branson, "Monetary and Fiscal Policy with Adjustable Exchange Rates," prepared for the Joint Economic Committee, Special Study on Economic Change (Government Printing Office, forthcoming). 
Table 1. Components of the U.S. Balance of Payments, 1960-77

Billions of dollars

\begin{tabular}{rrrrrr}
\hline Year & $\begin{array}{c}\text { Balance on } \\
\text { current } \\
\text { account }\end{array}$ & $\begin{array}{c}\text { Balance on } \\
\text { long-term } \\
\text { capital }\end{array}$ & $\begin{array}{c}\text { Basic } \\
\text { balance }\end{array}$ & $\begin{array}{c}\text { Balance on } \\
\text { short-term } \\
\text { capital }\end{array}$ & $\begin{array}{c}\text { Change in } \\
\text { reserves }^{\mathrm{b}}\end{array}$ \\
\hline 1960 & 2.8 & -4.4 & -1.6 & 1.8 & -3.4 \\
1961 & 3.8 & -3.7 & 0.1 & 1.4 & -1.3 \\
1962 & 3.4 & -4.6 & -1.2 & 1.5 & -2.7 \\
1963 & 4.4 & -6.0 & -1.6 & 0.3 & -1.9 \\
1964 & 6.8 & -7.1 & -0.3 & 1.2 & -1.5 \\
1965 & 5.4 & -7.4 & -2.0 & -0.7 & -1.3 \\
1966 & 3.0 & -6.0 & -3.0 & -3.2 & 0.2 \\
1967 & 2.6 & -6.7 & -4.1 & -0.7 & -3.4 \\
1968 & 0.6 & -2.9 & -2.3 & -3.9 & 1.6 \\
1969 & 0.4 & -4.4 & -4.0 & -6.7 & 2.7 \\
1970 & 2.3 & -6.3 & -4.0 & 5.9 & -9.9 \\
1971 & -1.4 & -9.1 & -10.5 & 19.2 & -29.7 \\
1972 & -5.7 & -5.1 & -10.8 & -0.6 & -10.2 \\
1973 & 7.1 & -7.9 & -0.8 & 4.5 & -5.3 \\
1974 & 2.1 & -6.1 & -4.0 & 4.7 & -8.7 \\
1975 & 18.3 & -17.3 & 1.0 & 5.4 & -4.4 \\
1976 & 4.6 & -15.3 & -10.7 & -0.2 & -10.5 \\
1977 & -14.1 & -14.8 & -28.9 & 6.1 & -35.0 \\
\hline
\end{tabular}

Source: William H. Branson, "Trends in United States International Trade and Investment since World War II," in Martin Feldstein, ed., The American Economy in Transition (University of Chicago Press, forthcoming), table 44.

a. Sum of the first and second columns.

b. Difference between the third and fourth columns.

after 1974. The net result is an increase in volatility in the basic balance from the 1960s to the 1970s. The time-series standard deviation increased from $\$ 1.5$ billion in 1960-69 to $\$ 7.8$ billion in 1970-77.

Short-term capital movements do not seem to have been particularly stabilizing, however. In the eight years from 1970 to 1977, the balance on short-term capital can be viewed as offsetting the basic balance only in 1972 and 1976, and there the quantity is trivial. This supports Dornbusch's inference that interest rate policies have not been aimed at stabilizing the external accounts. I read this evidence as being mildly supportive of the "Tobin tax."

To conclude, I think economists have come a long way in analyzing and understanding what is happening in international money and exchange rates, in the sense of positive economics. But policy prescription in the new environment is just beginning. 


\section{Comments by Marina v. N. Whitman}

Rudiger Dornbusch's paper provides an excellent vantage point from which to review the developments in exchange rate theory-or, alternatively, balance-of-payments theory-during the past decade. In some aspects, it appears to bring us full circle to some of the views that prevailed before what might be called the "global monetarist" revolution of the 1970s in which, as William Branson has already pointed out, Dornbusch was a major participant. In other aspects, this paper is a measure of how far economists have come in understanding the determination of exchange rates and their interactions with other macroeconomic variables in open national economies.

As background, the early 1970s were dominated in the real world by the shift from pegged to flexible, though managed, exchange rates, and in the academic world by the shift from a Keynesian flow-equilibrium view of the balance of payments-or the exchange rate-to a stock-equilibrium, asset market view. The differences between the two approaches are by now quite familiar. They include, first, a shift from the definition of equilibrium in medium-run flow terms to its definition in long-run stationary-state stock terms; and second, a shift in focus from goods markets to asset markets or, to put it in somewhat oversimplified terms, from the balance of trade to the balance of payments.

Third, there was a shift in emphasis from real variables, including the real terms of trade, to financial or monetary variables. In addition, the more monetarist versions of this new view stressed the long-run neutrality of money and the maintenance of purchasing power parity (PPP), the importance of commodity arbitrage in shortening up the long run and, finally, the endogeneity of the money supply under pegged exchange rates.

Dornbusch begins this paper, in contrast, by emphasizing the inadequacy of PPP and discussing its theoretical weaknesses. He focuses not so much on the standard problems surrounding the choice of the correct 0007-2303/80/0195-0202\$01.00/0 (C) Brookings Institution 
price index or of an equilibrium base period, but instead on the fact that both the PPP concept and the Keynesian interest rate parity are reducedform relations rather than structural ones, meaning that they do not describe behavioral relations, do not make explicit what is included in "other things equal," and do not relate directly to policy variables.

He notes that, in the short run, price stickiness and nonneutrality of money obviate the PPP relationship. He does not say much about its applicability in the long run, although others have noted that, even in the case of a purely monetary disturbance, the exchange rate consistent with the new long-run stock equilibrium may not bear a pure PPP relation to the original exchange rate. This can occur, for example, if during the transition period the redistribution of wealth that takes place through current account imbalances alters the size of the net flows of interest income in the new equilibrium and, thus, the equilibrium real terms of trade (that is, those corresponding to a zero balance on the current account). ${ }^{1}$

Dornbusch then discusses some empirical findings, which essentially show that PPP does not hold well over the 1973-79 period for a number of major currencies. He also shows that significant changes have occurred in real exchange rates, both bilateral and "effective" or trade-weighted composites, implying the need to model rather than to ignore changes in real exchange rates. Dornbusch adduces empirical evidence indicating that the second leg of the monetary approach, the proposition that interest rate differentials mirror differentials in inflation rates, does not hold either. I will return to the reasons why below.

Dornbusch emphasizes the central role of the current account. His whole approach stresses the distinction between this account and the rest of the balance-of-payments accounts, rather than drawing the line further down, between the money account and everything else; that is, in terms of Branson's distinction, he places himself much closer to New Haven than to Chicago.

He also allows the possibility of an initial and persistent disequilibrium in various markets. In this connection, he notes the role of desired port-

1. For a discussion of this point, see Peter Isard, Exchange-Rate Determination: A Survey of Popular Views and Recent Models, Princeton Studies in International Finance, 42 (Princeton University, International Finance Section, May 1978), p. 30; and Louka T. Katseli-Papaefstratiou, The Reemergence of the Purchasing Power Parity Doctrine in the 1970's, Special Papers in International Economics, 13 (Princeton University, International Finance Section, December 1979), pp. 14-16. 
folio diversification in determining the exchange rate and, in his framework, this portfolio diversification is accomplished gradually rather than instantaneously.

As far as Dornbusch's model of exchange rate determination, circa 1980 , is concerned, his presentation is sufficiently elliptical that I have filled it out a bit in what follows by bringing to bear some points that have been made explicitly by other authors but that I think are implicit in this paper, or at least are consistent with it. Parenthetically, I think Dornbusch's exposition demonstrates some of the difficulties of trying to project the essentials of a seven-equation dynamic differential equation model with three state variables onto two-dimensional graphs.

Three groups of factors determine the exchange rate in his model. The first is relative inflation rates, which are composed of trend or expected rates and cyclical components. These rates are presumably not fully reflected in interest rate differentials for two reasons: the cyclical component is not fully anticipated in his model; and the monetary policies or the state of the credit markets may differ. In other words, tighter or looser monetary policy, in the popular nomenclature, can produce temporary differences among countries in real interest rates.

The second determinant of exchange rates consists of portfolio balance requirements, including risk diversification considerations derived from the Tobin-Markowitz-Sharpe asset market models. These models regard assets denominated in different currencies as imperfect substitutes and produce yield differentials consistent with equilibrium, in the form of a risk premium.

This risk premium, in turn, depends in part on relative supplies of outside assets denominated in different currencies-supplies determined by the interactions of monetary policies, government budget deficits and official intervention in the exchange markets. ${ }^{2}$ The risk premium also depends on the relative demands for assets denominated in different currencies, which are determined by shifts in portfolio preferences. These depend in turn on the variances and covariances of real yields on different assets and on both actual and expected shifts in the distribution of wealth through current account imbalances.

2. Michael P. Dooley and Peter Isard, "The Portfolio-Balance Model of Exchange Rates," International Finance Discussion Paper 141 (Board of Governors of the Federal Reserve System, May 1979), p. 5. 
The third group of factors affecting the exchange rate are those that affect the equilibrium real terms of trade; namely, changes in the level and composition of demand. Thus, to generate unanticipated changes in exchange rates, the model is cast in terms of the effects of income and current account "surprises": income is associated with the level of demand, and the current account is associated with its composition.

If all three of these groups of factors are put together, they imply three different effects of the current account on the exchange rate. This is rehabilitation of the current account with a vengeance.

Two of these effects are indirect. One is that stemming from wealth redistribution through imbalances in the current account, which leads by distributional effects in asset markets to the need for offsetting changes in exchange rates to restore equilibrium. The other arises from the changes in relative supplies of assets denominated in different currencies, which are brought about by the financing of current account imbalances in a world of what are, at least intermittently, managed rather than purely flexible rates.

A more direct effect is that current account shifts serve in this model as signals for equilibrium changes in real relative prices to be brought about by exchange rate movements. I believe this effect is grounded in an assumption, which, again, is not made explicit here but is discussed elsewhere by Isard. ${ }^{3}$ The assumption is that market participants expect real rates to shift in such a way that they prevent the infinite accumulation of current account imbalances in either direction.

Finally, Dornbusch ties his model to rational expectations. That is, he assumes that people know and act immediately on the systematic components of the economic environment in which they live. Unfortunately, the systematic components tend to be dominated by unsystematic or random components.

This assumption of rational expectations does not provide a stable anchor for expectations by which one can connect the short run with long-run equilibrium exchange rates and make the latter determinate. Elsewhere, again, Isard has suggested that one can create such an anchor if one assumes that market participants evaluate new information about

3. Peter Isard, "Expected and Unexpected Changes in Exchange Rates: The Roles of Relative Price Levels, Balance-of-Payments Factors, Interest Rates and Risk," International Finance Discussion Paper 156 (Board of Governors of the Federal Reserve System, April 1980), p. 8. 
price variables on the expectation that exchange rates will exhibit PPP in the long run, and that they evaluate new information about balance of payments or real terms-of-trade factors on the expectation that the time path of real exchange rates will avoid current account imbalances from accumulating indefinitely, which seems eminently reasonable. ${ }^{4}$

But even this pair of expectations, it seems to me, is sufficient to assure determinacy only if there is no feedback from exchange rates to behavioral parameters. Otherwise, short-run departures from long-run equilibrium will alter the latter. That is, there is no guarantee that if one gets off the stable expectations path for any reason, one will necessarily get back to it.

The fact that changes in monetary and intervention policies affect not only spot interest and exchange rates but also expectations about future rates, incidentally, explains why interest-parity forecasts are such poor predictors of spot rates.

In what sense is all this an amalgam of the old and the new? It brings the story full circle; that is, it returns to the Keynesian conventional wisdom in several respects. One is the emphasis on goods markets, on the level and composition of demand-and output is demand-determined in this model-and thus on the importance of the current account in determining exchange rates. (The capital account, to which I will return below, is viewed as secondary, not only in a positive sense but also, rather subtly, in a normative one.) The model also incorporates price stickiness, persistent deviations from PPP, and real price changes through changes in the exchange rate. Finally, it allows for persistent disequilibria in exchange markets, in particular the famous dollar surplus or overhang, or deutsche mark shortage, however one prefers to characterize it. The model thus incorporates several important aspects of the conventional wisdom that may have disappeared from the universities during the 1970 s but that never really disappeared from the streets.

On the other hand, there are many new factors reflected here that are derived from the monetary revolution of the 1970s. In fact, all the old factors I just mentioned are embedded in a new framework.

Dornbusch's formulation incorporates stationary-state stock equilibrium conditions and stock-flow interactions. He discusses the dynamics of the difference between short-run and long-run effects of disturbances as

4. Ibid. 
well as the transition paths. He accounts for asset markets and commodity markets and in that sense presents us with a general equilibrium framework. He links the future and the present through expectations. His model is grounded in rational expectations plus "surprises," making an important distinction between anticipated and unanticipated events. Finally, he incorporates portfolio diversification considerations from asset market theory.

What are the implications of this new eclecticism for hypothesis testing? The Dornbusch formulation implies that the appropriate variables for explaining changes in the exchange rate are forecast errors rather than realized magnitudes. This has a radical implication for exchange rate forecasting, which is, in essence, that it cannot be done. His model thus provides a very elegant rationale for why it is impossible to forecast exchange rates successfully in a world dominated by the unexpected.

A corollary of this main point is that one cannot predict the effects of policy shifts on exchange rates unless one knows whether they are anticipated or unanticipated, by now not a new idea. Furthermore, it provides an explanation of why forward rates are such poor predictors of future spot rates.

What are the implications for policy? In general, the approach Dornbusch takes here is much more interventionist than that of the monetarists so that, in yet another respect, Keynesianism emerges again. (This link between Keynesianism and interventionism is not a logically necessary association, but it is certainly an empirically observable one.) Dornbusch's interventionism arises both because he allows persistent disequilibria in various markets and because he sees volatility as inherent in the system and not just due to stupidity or insufficient stabilizing speculation or other correctable market imperfections.

Specifically, his view offers an argument for intervention as a possible anchor for expectations. He raises no objection to the "smoothing" that seems to have dominated observed official intervention, and he gives what is essentially Mussa's argument about the government's buying credibility for its policies by "putting its money where its mouth is" through exchange-market intervention. ${ }^{5}$

In other words, while governments in general may not be able to predict the future better than anyone else, they may be better predictors of

5. Michael Mussa, "The Role of Official Intervention," paper prepared for the Group of Thirty, February 1980, pp. 30-32. 
their own future behavior than participants in the private market. However, and this brings me to a second policy implication of the Dornbusch analysis, this would only be true if such intervention were coupled with far greater predictability of the policy environment than exists today. Such predictability is crucial in a world where exchange-rate volatility is due primarily to the interaction between surprises or "news" and rational expectations, which leads to discontinuous jumps in spot rates.

In evaluating how well the present system works, Dornbusch gives fairly high marks to intervention when it is used for smoothing, but not when it has so-called cyclical components (that is, anticyclical effects domestically), which he terms "beggar-my-neighbor" behavior. He also gives a fairly optimistic assessment of the cyclical stabilization role played by interest rates under managed flexibility and to the ability of changes in the exchange rates to bring about current account adjustment. The problems lie, in his view, in the destabilizing role of capital flows, to which he assigns essentially second-class citizenship, suggesting implicitly that they do not contribute to the maximization of world efficiency or economic welfare in the same way that international commodity flows do. As a result of the destabilizing behavior of capital flows, Dornbusch argues, current account adjustment comes at the cost of substantial exchange rate volatility.

Dornbusch rejects a Tobin, or transactions, tax on foreign exchange transactions as a means of alleviating the volatility problem. But he does so for essentially interventionist rather than free-market reasons, that is, because of its effect on the autonomy of government actions rather than on the autonomy of participants in the private market. In any case, this rejection leads him to some schizophrenia about the use of monetary policy. Should it be directed externally, toward stabilizing exchange rates, or internally, toward the stabilization of domestic income, as it apparently has been in most major industrial countries?

Reflection on this very interesting and provocative paper leaves me with two final questions. Is there danger in letting the tail wag the dogemphasizing exchange rate stability as an end in itself rather than as a means to achieve worldwide stability and growth of income, which is presumably the ultimate goal? And must economists again address Robert Mundell's old problem of having one policy instrument too few-a problem referred to rather obliquely here as "the question of creating a better policy mix"-despite today's flexible rather than pegged rates? Has this 
shift really resolved the problem of needing as many policy instruments as there are policy targets, as the literature of the prerevolutionary era seems to suggest?

In sum, the amalgamation of the old wisdom of the 1950s and 1960s with the new wisdom of the 1970s found in this paper brings a great deal of new understanding yet leaves many old questions still unanswered as we start the 1980s. 


\section{General Discussion}

Rudiger Dornbusch differed with Branson's emphasis on the importance of the current account-portfolio channel. He noted that the differences in national portfolio diversification preferences depend on differences in consumption patterns and on real exchange-rate variability. The role of these factors in influencing exchange rate movements may well be small relative to the influence of changes in the relative supplies of outside assets created through budget deficits or intervention. Dornbusch added that, in some cases-such as the recent appreciation of the pound sterling-terms-of-trade effects could dominate any portfolio considerations.

Dornbusch also disagreed with Branson's reading of the empirical evidence on the impact of fiscal expansion on the exchange rate. He noted work by John Helliwell showing that, for the United States and Canada, a fiscal expansion, given nominal money, leads to currency appreciation in the expanding country. Dornbusch also pointed out that, in contrast to Branson's characterization, his early work did explore the roles in exchange rate determination of current accounts and imperfect asset substitution.

Peter Kenen suggested modeling two processes that are mirrored in the current account: disturbances that impinge directly on the goods market and that change the terms of trade in the long run, and saving and dissaving. Leaving goods-market disturbances aside, PPP governs exchange rates in the long run. Instantaneously, exchange rates clear asset markets. Saving determines the current account and the evolution of the exchange rate to its long-run equilibrium. The exchange rate is thus an asset market phenomenon in the short run; while its evolution to long-run equilibrium is governed by saving, or its counterpart, the current account balance.

Kenen endorsed Marina Whitman's observations that one of the expected advantages of flexible exchange rates is the greater autonomy that system would provide to monetary policy. Until more is known about 
its costs and benefits, he could see little basis for making exchange rate stability a major goal of monetary policy. Hendrik Houthakker countered that monetary policy autonomy is desirable only when the policies followed are wise; he believed that until recently U.S. polices have been particularly poor and that fixed exchange rates might be preferable for the discipline they imposed on the monetary authorities. Robert Hall noted that Dornbusch's analysis supports the policy of issuing bonds denominated in foreign currency so as to allow the domestic monetary authorities to stabilize their currencies while adhering to their domestic monetary growth targets even when these are associated with low interest rates.

Houthakker was intrigued by the close association that Dornbusch found between real interest rates and the current account. This indicated that the system was quickly bringing about exchange rate movements that would adjust current account imbalances.

Several panel members suggested additions to the analysis. Kenen questioned the ability of Dornbusch's current account measure to capture surprises adequately and suggested that equations that explain actual rather than unanticipated movements might perform better. But Dornbusch replied that intervention equations with unanticipated changes are more stable and have less serial correlation. Robert Lawrence suggested that the effective deutsche mark exchange rate might give better results than the bilateral dollar-deutsche mark rate. Houthakker reasoned that OPEC should have been treated explicitly in the analysis along with developing countries. But Dornbusch argued that OPEC should be treated as one of many investors in his model. However, George Perry suggested that unlike other investors, OPEC might have to take the effects of its own actions into account.

William Fellner observed that if, for whatever reason, nominal interest rate differentials failed to reflect expected inflation differentials, movements in the spot exchange rates would be large. In order to maintain PPP in the long run, the spot rate would move in response to changes in those expectations to the point at which expected future exchange rate movements plus the sticky interest differential approximate the expected inflation differential. These changes in exchange rates constitute part of the yield expected by diversifying investors. An important reason why interest differentials do not adjust fully, and why spot rates consequently moved so much, is that the bulk of dollar holders, generally U.S. resi- 
dents, are unlikely to diversify since they would be increasing the risks important to them by doing so.

A number of other comments were addressed to Dornbusch's hypothesis of a deutsche mark shortage. Lawrence believed the real puzzle is why diversification toward marks has proceeded so slowly. He suggested that reluctance by German officials to assume a reserve currency role might have attenuated some of the trend toward diversification in the past; and he noted that German officials now seem more inclined to accept such a role. William Brainard questioned the reliability of treating ex post yields and covariances in the portfolio analysis as if they were ex ante structural parameters. The substantial negative covariance itself may simply reflect the unanticipated appreciation of the mark. He noted that Dornbusch had shown that most of the ex post exchange rate movements were unanticipated; consequently, they could not have entered into typical portfolio decisions. Alternatively, if the difference between the mean real return on dollars and marks over the period studied is treated as anticipated, as its use in Dornbusch's portfolio analysis implies, it indicates an implausibly large degree of risk aversion-the 7 percentage point differential in real returns results in an optimal portfolio of only 56 percent marks compared with 50 percent marks in the minimumvariance portfolio. George von Furstenberg noted that official portfolios are included in the total movement away from dollars. He pointed out that officials are constrained in their reserve portfolio allocations and are likely to diversify to other currencies only when the dollar is strong. 